\title{
Biochemical characterisation of potentially contagious haemic neoplasia occurring in the Baltic clam Limecola balthica
}

\section{Hallmann Anna}

Medical University of Gdańsk

Michnowska Alicja

University of Gdańsk

Chomiczewska Agnieszka

Medical University of Gdańsk

Lipiński Marcin

Medical University of Gdańsk

Smolarz Katarzyna ( $\nabla$ katarzyna.smolarz@ug.edu.pl )

University of Gdańsk

\section{Research Article}

Keywords: leukemia-like neoplasia, energy homeostasis, FAA, ROS, mitochondrial respiration, Limecola balthica

Posted Date: April 29th, 2021

DOI: https://doi.org/10.21203/rs.3.rs-468774/v1

License: (c) (1) This work is licensed under a Creative Commons Attribution 4.0 International License. Read Full License 


\section{Biochemical characterisation of potentially contagious haemic neoplasia occurring in the Baltic clam Limecola balthica}

Hallmann Anna ${ }^{1}$, Michnowska Alicja ${ }^{2}$, Chomiczewska Agnieszka ${ }^{1,3}$, Lipiński Marcin ${ }^{1}$, Smolarz Katarzyna ${ }^{2 *}$

1. Department of Pharmaceutical Biochemistry, Medical University of Gdańsk, Gdańsk, Poland

2. Department of Oceanography and Geography, University of Gdańsk, Gdynia, Poland

3. Department of Biochemistry, Medical University of Gdańsk, Gdańsk, Poland

Contact person:

*Smolarz Katarzyna, email address katarzyna.smolarz@ug.edu.pl

Key words: leukemia-like neoplasia, energy homeostasis, FAA, ROS, mitochondrial respiration, Limecola balthica 


\begin{abstract}
Occurring in marine invertebrates haemic (leukemia-like) neoplasia, a disease of potentially infectious nature, arises from genome instabilities leading to multilevel malfunctions and unregulated cell division of presumably haemocyte precursors. As its biochemical characterisation remains unknown, we here present results describing selected physiological and biochemical aspects of the disease measured in neoplastic and healthy clams Limecola balthica. Activities of adenosine deaminase (ADA), alkaline phosphatase (ALP) and FAA levels were measured in haemolymph but no differences in ADA and ALP activities between healthy and neoplastic clams were found. In both clam groups nine FAAs were detected with Asp, Glu, Pro, Ser constituting over $90 \%$ of total FAA content. Significantly higher GIn level was detected in leukemic-like clams suggesting an essential role of this FAA in cancer energy production. In neoplastic cells, an impairment of mitochondrial metabolism was observed as a decrease in mitochondrial oxygen consumption and lower cytochrome c oxidase activity. Neoplastic clams were also characterised by significantly higher concentration of ROS, but no elevated response of the oxidative stress markers were found suggesting an efficient antioxidant response. Finally, we, for the first time, report high levels of corticosterone and lower amounts of dehydrocorticosterone, cortisol and cortisone in healthy clams with elevated cortisol level found in neoplastic individuals.
\end{abstract}




\section{Introduction}

Neoplasia is generally considered as a prominent disease among vertebrates, occurring in both terrestrial and aquatic animals. It is estimated that neoplasms affect over 120 families and 302 wild species, including mammals, birds, reptiles, amphibians and fish ${ }^{1}$. The disease is also detected in various species of invertebrates, some of them commercially and ecologically important ${ }^{2-4}$. Disseminated neoplasia, a tumor originating from unregulated cell division presumably of haemocyte precursors, resembles leukemia occurring in vertebretes, thus it is also called haemic neoplasia or leukemia-like neoplasia. Distinctive cell morphology (cellular and nuclear polymorphism, hypertrophy and anaplasia), high mitotic activity, and a high level of aneuploidy are typical for the disease ${ }^{5,6}$. Leukemia-like neoplastic cells are also characterised by lower or even absent phagocytic ability, relocation of the p53 tumour suppressor protein and new surface antigens ${ }^{7-9}$. These characteristics, especially cytoplasmic sequestration of p53 protein, may significantly reduce the effectiveness of defensive mechanisms in the transformed cells ${ }^{8,10}$.

As most cancers, also haemic neoplasia found in bivalves arises from genome instabilities, whether induced or spontaneous, that lead to multilevel malfunctions of affected organism. Historically, a role of pollutants in genome destabilization and induction of the disease was suggested, but its aetiology is unclear ${ }^{11}$. Also, immunosuppression may stimulate the progression of the disease as immune malfunctions lead to incorrect responses towards external stressors or can even directly act as carcinogenic factors ${ }^{12,13}$. Other data suggest that disseminated neoplasia may belong to diseases of infectious nature, possibly transmissible by cohabitation of healthy and neoplastic animals in large bivalve assemblages ${ }^{14,15}$. Recent studies of Metzger et al. ${ }^{16,17}$ reported the occurrence of horizontal transmission of cancer cells in four marine mollusks: Mya arenaria, Cerastoderma edule, Mytilus trossulus and Polititapes aureus. Malignant cells are thus potentially able to survive the transit in seawater, to overcome self-recognition systems of a host and form precursor lesions of haemic neoplasia ${ }^{16,17}$. As such, identifying physiological and biochemical aspects of contagious cancers in marine invertebrates opens a new avenue not only for studying cancer epidemiology in wildlife, but also for using disseminated neoplasia as a model in cancer research. Indeed, some characteristics such as immunosuppression, altered respiration pathways and energetic metabolism may be similar in both leukemia-like and leukemia cancers. Yet, specific biochemical characterisation of this leukemia-like cancer remains largely unknown.

In bivalves, hemolymph, as an equivalent of blood in vertebrates, plays a key role against external assault as it participates in various immune responses and may be first affected by leukemia-like cancer. Hemocyte morphology, concentration, viability, intracellular oxidative activity, lysosomal 
content and phagocytotic capacity were already used as a proxy of bivalve immune efficiency also in individuals affected by haemic neoplasia ${ }^{18,19}$. In vertebrates, alteration in various enzyme activities in serum have been reported in malignancies such as leukemia ${ }^{20}$, and this data is lacking for neoplastic disorders developing in marine bivalves. For example, alkaline phosphatase (ALP), an important lysosomal enzyme participating in various metabolic and developmental processes, is a zinc metalloenzyme catalyzing the hydrolysis of phosphate esters. The enzyme has been used as a diagnostic marker of acute myelomonocytic and monocytic leukemia in, for example, dogs ${ }^{21}$. Another haemolytic enzyme, adenosine deaminase (ADA), is involved in purine metabolism, inflammatory response and cytokine production, and thus participates in development and maintenance of the immune system. The enzyme was detected in prokaryotic and eukaryotic species and is characterised by a high conservation of aminoacid sequence ${ }^{22}$. In bivalves, the size, optimum $\mathrm{pH}$, and substrate specificity of ADA isolated from adductor muscle of Patinopecten yessoensis and Mactra chinensisthe were similar to those of vertebrate ADA ${ }^{23}$. However, in lower organisms, despite being detected, the enzyme's main biological function remains unclear. In vertebrates, leukemic cells are characterised by an increased ADA activity caused by elevated synthesis of a structurally normal enzyme that serves as a usefull marker of leukemia progression ${ }^{24}$. Yet, there is no data neither on ALP or ADA activity in the hemolymph nor on its relationship with haemic neoplasia in bivalves.

Corticosteroids are steroid hormones that regulate the metabolism of proteins, carbohydrates and fats, which is of crucial importance for the body's energy homeostasis. They are also known for their anti-inflammatory and immunosuppressive abilities ${ }^{25}$. The final metabolites of the corticosteroid synthesis pathway include dehydrocorticosterone (D-CRT), corticosterone (CRT), cortisone (CN) and cortisol (HCN). CYP11B1 (11ß-hydroxysteroid hydroxylase) enzyme catalyses the production of CRT and HCN, with D-CRT and CN being their inactive metabolites. CRT and HCN have 11-hydroxysteroid structure determining their affinity to glucocorticoid receptors in cells, thus exerting hormonal action. However, synthesis and hormonal activity of cortisol has so far been documented mainly in Primates, while corticosterone is known to occur in other animal species. In vertebrates, corticosteroids are also used in leukemia treatment as they have the ability to destroy the leukemia cells ${ }^{26}$. In invertebrates, and especially in marine bivalves, the levels, the role and the origin of corticosteroids (glucocorticoids in particular) are not well underestood, particularly in neoplastic disorders. Yet, it is known that in this group of organisms, hemocytes are the main source of various hormones such as adrenocorticotropic hormone (ACTH), corticotropin-releasing hormone (CRH) and some biogenic amines ${ }^{27,28}$.

Neoplastic cells found in invertebrates have ultrastructural features in common with malignant vertebrate cells. This includes ultrastructures involved in energy metabolism, such as mitochondria and Golgi complexes ${ }^{4}$. In neoplastic disorders, the Warburg effect is a commonly accepted theory 
explaining cancer energy metabolism. The Warburg effect shifts the metabolic pathway of ATP generation in cancer cells from mitochondrial oxidative phosphorylation to anaerobic glycolysis and production of lactate. Hence, mitochondrial energetic functions of those cells are suppressed, and, as a consequence, decreasing activities of electron transport complexes and lowered oxygen consumption by mitochondria occur ${ }^{29}$. Indeed, according to Galuzzi et al. ${ }^{30}$ formation of ATP in cancer cells is coupled to comparatively low levels of oxidative phosphorylation. Recent findings highlighted that in cancers such as murine lymphoblastic leukemia leukemic cells lose their capacity for mitochondrial respiration at the level of complex I (NADH-coenzyme Q reductase) and complex II (succinate-coenzyme $Q$ reductase), the major sites for entry of electrons into the respiratory chain ${ }^{31}$. However, despite being an extremely important factor potentially boosting cancer pathogenicity, energy metabolism in leukemia-like and potentially contageous cancers occurring in invertebrates is unknown. Also, other important end products, substrates and/or intermediates of anaerobic energy metabolism supporting all crucial life functions in marine invertebrates are free amino acids (FAA) ${ }^{32}$. Studies on FAA in bivalves have been carried out for purposes such as investigating their nutritional parameters, role in osmoregulation and their involvement in the metabolism. It is a common knowledge that FAA levels in the tissues of aquatic organisms change seasonally and under environmental stress ${ }^{33,34}$. Yet, FAA levels can also change as a response to worsening physiological conditions and the organism's heath status. In humans, hypoaminoacidemia (AAN $<5.9 \mathrm{mg} / 100 \mathrm{ml}$ ) occurred in $60 \%$ of the patients with acute leukemia ${ }^{35}$. Moreover, decrease of taurine level seems to be typical in acute myeloid leukemia ${ }^{36}$.

The main objective of this study was to describe markers of cancers affecting marine invertebrates that can increase our knowledge about environmental carcinogenesis. For that, we used the Baltic clam Limecola balthica (former Macoma balthica) as a model species and leukemia-like neoplasia as a model disease in which selected biochemical and metabolic markers were measured. These included glycolytic capacity of cancers developed from respiration pathways, ROS production, FAA levels, enzymatic activity in the haemolymph and the whole organism and neurotransmission pathway. The aim was also to validate the concept of the biochemical uniformity of neoplastic diseases among vertebrate and invertebrate species for a future use of haemic neoplasia as a model cancer.

\section{Materials and methods}

Approx. 200 L. balthica were collected onboard of $R / V$ Oceanograf using a benthic sledge in the Gulf of Gdańsk (Baltic Sea, Poland) at a sampling location historically characterized by a high frequency of neoplasia ${ }^{5}$. After transportation to the laboratory, clams were opened, and haemolymph samples 
were collected from the pericardium or adductor muscle using microliter glass syringes. Preliminary neoplasia diagnosis was performed under light microscope based on haemolymph subsample stained with $0,5 \%$ methylene blue. For further analyses 46 healthy and 39 animals with a majority of neoplastic cells in the haemolymph were selected. Individuals were treated according to three main protocols as described below. The first protocol included measurement of enzymatic activities (section 2.1) and FAA levels (section 2.2) in the haemolyph. Remaining soft tissue was stored in Davidson fixative for 48 $\mathrm{h}$, transferred to $4 \%$ buffered formaldehyde solution and stained using basic histology protocols with H\&E. This set of samples (12 healthy and 11 neoplastic individuals) was also used for final diagnosis of neoplasia and for assessing the accuracy of preliminary diagnosis based on haemolymph sample (Fig. 1a-e). Second protocol included an assessment of the antioxidative and responses of biomarkers of physiological stress. For that purpose, after neoplasia diagnosis, the remaining soft tissue was immendiately frozen in liquid nitrogen and further stored in $-80^{\circ} \mathrm{C}$ until the analyses described in the section 2.4 were performed. Here, 6 healthy and 6 neoplastic clams were selected. Final protocol included measurement of mitochondrial respiration in 18 healthy and 13 neoplastic individuals. Among those, in 10 healthy and 10 neoplastic clams analyses of corticosteroids level were performed. Here, mitochondria were isolated from the haemolymph sample while the soft tissue was homogenized and further processed as described in the section 2.3 and 2.5 .

\subsection{Measurement of enzymatic activities in the haemolymph samples}

\subsubsection{Adenosine deaminase (ADA, EC 3.5.4.4) activity}

For haemocyte isolation, the haemolymph sample was centrifuged ( $2000 \mathrm{xg}$ for $10 \mathrm{~min}, 4{ }^{\circ} \mathrm{C}$ ), $50 \mu \mathrm{l}$ of supernatant was pipetted, mixed with $1 \mu \mathrm{l}$ of $1 \mathrm{mM}$ adenosine, and incubated for 1.5 minutes at room temperature. After incubation, $50 \mu \mathrm{l}$ of $1.3 \mathrm{M} \mathrm{HClO}_{4}$ was added to inhibit enzymatic activity. After 15 minutes on ice, samples were centrifuged ( $14000 \times \mathrm{g}$ for $10 \mathrm{~min}$, at $4^{\circ} \mathrm{C}$ ), the supernatant was acidified to $\mathrm{pH}$ 5-6 with $3 \mathrm{M} \mathrm{K}_{3} \mathrm{PO}_{4}$ and again centrifuged (14000 $\times \mathrm{g}$ for $10 \mathrm{~min}$, at $\left.4^{\circ} \mathrm{C}\right)$. A control was prepared for each measurement by addition of $1.3 \mathrm{M} \mathrm{HClO}_{4}$ before $1 \mathrm{mM}$ adenosine. All samples were analysed using HPLC. The ADA activity was assessed by determination of reaction products content as described by Smolenski et al. ${ }^{37}$ and its activity was calculated in $\mathrm{nmol} / \mathrm{min} / \mathrm{mL}$.

\subsubsection{Alkaline phosphatase (ALP, EC 3.1.3.1) activity}

ALP activity was determined using a commercially available test kit (R-R-A-pS-V-A 17-128, SigmaAldrich). ALP was detected using Malachite Green Detection System with phosphopeptide as a substrate (one unit of activity is equivalent to $1 \mathrm{nmol}$ pNPP hydrolyzed per minute). Enzyme activity was expressed in $\mathrm{nmol} / \mathrm{min} / \mathrm{mL}$. 


\subsection{Free Amino Acids (FAA) in haemolymph samples}

FAA concentrations were determined according to Olkowicz et al. ${ }^{38} .10 \mu \mathrm{L}$ of the internal standard solution (2-chloroadenosine) was added to $50 \mu \mathrm{L}$ of haemolymph (without hemocytes), and the solution was extracted with $120 \mu \mathrm{L}$ of acetonitrile. Samples were precipitated for 30 minutes in ice, centrifuged $14000 \times \mathrm{g}$ at $4^{\circ} \mathrm{C}$ for 20 min., the supernatant was transferred into new tubes and freeze dried. The samples were dissolved in $100 \mu \mathrm{L}$ water, centrifuged for $15 \mathrm{~min}$ at $14000 \times \mathrm{g}, 4^{\circ} \mathrm{C}$ and analysed using high performance liquid chromatography-mass spectrometry (LC/MS) on a Surveyor HPLC system coupled with a TSQ Vantage Triple-Stage Quadrupole mass spectrometer (Thermo Fisher Scientific, Waltham, MA, USA). Heated electrospray ionization in positive mode was used. Chromatographic separation was achieved with a $50 \times 2 \mathrm{~mm}$ Synergi Hydro-RP 100 column with a 2.5 $\mu \mathrm{m}$ particle size (Phenomenex, Torrance, CA, USA). The mobile phase consisted of water with $5 \mathrm{mM}$ nonafluoropentanoic acid (Buffer A) and acetonitrile with 0.1\% formic acid (Buffer B). $2 \mu \mathrm{L}$ aliquots of samples were injected into a column eluted with a mobile phase at a flow rate of $0.2 \mathrm{~mL} / \mathrm{min}$. Based on the retention times of individual amino acid standards, the identities of amino acids in the samples were determined and compared to the peaks of corresponding standards. The procedure was followed by calculation of quantities of individual amino acids.

\subsection{Measurement of mitochondrial respiration and enzymatic activities}

Used reagents include substrates: succinic acid, malic acid, pyruvic acid, ADP, inhibitors: rotenone (complex I inhibitor), antimycin A (complex III inhibitor), oligomycin (ATPase inhibitor), and ascorbate with N1,N1,N1,N1-tetramethyl-1,4-phenylene diamine (TMPD) as electron acceptor, carbonylcyanide3-chlorophenylhydra-zone (CCCP) as ionophore (uncoupler).

\subsubsection{Mitochondrial isolation}

Mitochondria were isolated according to Schnaitman and Greenawalt ${ }^{39}$ with some modifications. Single clam soft tissue was homogenised in $1 \mathrm{ml}$ of MSHE buffer ( $70 \mathrm{mM}$ sucrose, $210 \mathrm{mM}$ mannitol, 5 mM HEPES, $1 \mathrm{mM}$ EGTA and 0.5\% BSA (fatty acid free), $\mathrm{pH} 7.2$ ) at $4^{\circ} \mathrm{C}$ using glass homogenizer. Homogenate was centrifuged at $800 \times \mathrm{g}$ for 10 minutes at $4^{\circ} \mathrm{C}$, obtained supernatant was centrifuged at $8000 \mathrm{xg}$ for 15 minutes at $4^{\circ} \mathrm{C}$ and the pellet was resuspended in MSHE buffer. Total mitochondrial protein $\left(\mathrm{mg} / \mathrm{mL}\right.$ ) was determined using the Bradford Assay reagent (Bio-Rad) and Bradford ${ }^{40}$ method.

\subsubsection{Mitochondrial respiration}

Mitochondrial respiration was measured by the Agilent Seahorse XFp analyzer (Agilent Technologies, MA, USA). For analysis of mitochondrial coupling efficiency, the plate containing $25 \mu \mathrm{g}$ mitochondria per well in $25 \mu \mathrm{L}$ mitochondrial assay buffer (MAS; $70 \mathrm{mM}$ sucrose, $220 \mathrm{mM}$ mannitol, $10 \mathrm{mM} \mathrm{KH}_{2} \mathrm{PO}_{4}$, 
$5 \mathrm{mM} \mathrm{MgCl} 2,2 \mathrm{mM}$ HEPES, $1 \mathrm{mM} \mathrm{EGTA}$ and $0.2 \% \mathrm{BSA}$ (fatty acid free), pH 7.2) was centrifuged ( $2000 \mathrm{x}$ g, $15 \mathrm{~min}, 4^{\circ} \mathrm{C}$ ) and $155 \mu \mathrm{l}$ MAS containing $10 \mathrm{mM}$ succinate pre-warmed to $20^{\circ} \mathrm{C}$ was used. After calibration, the mitochondria plate was inserted. After $10 \mathrm{~min}$, two cycles (1 min mixing, 3 min waiting time) were followed by three cycles ( 1 min mixing, 1 min waiting, 3 min measurement). The protocol applied before each injection included 2 min mixing and 1 min waiting, addition of the indicated compound, $1 \mathrm{~min}$ waiting and a final measurement ( $3 \mathrm{~min})$. At the indicated time points, $4 \mathrm{mM} \mathrm{ADP}$, $2.5 \mu \mathrm{g} / \mathrm{mL}$ oligomycin $\mathrm{A}, 4 \mu \mathrm{M}$ CCCP and $4 \mu \mathrm{M}$ antimycin A were added.

For analysis of the electron transport chain (ETC) complexes activities the plate containing $25 \mu \mathrm{g}$ mitochondria per well in $25 \mu \mathrm{L}$ MAS was centrifuged ( $2000 \times \mathrm{g}, 15 \mathrm{~min}, 4^{\circ} \mathrm{C}$ ) and $155 \mu \mathrm{l}$ MAS containing $10 \mathrm{mM}$ pyruvate, $2 \mathrm{mM}$ malate and $4 \mu \mathrm{M} \mathrm{CCCP}$ prewarmed to $20^{\circ} \mathrm{C}$ were used. In the same time sequence as in mitochondrial coupling assay, at the indicated time points, final concentrations of $2 \mu \mathrm{M}$ rotenone, $10 \mathrm{mM}$ succinate, $4 \mu \mathrm{M}$ antimycin $\mathrm{A}$ and $10 \mathrm{mM}$ ascorbate plus $100 \mu \mathrm{M}$ TMPD were added. Oxygen consumption rates (OCR; pmol/min) were calculated by the Wave software (Seahorse Bioscience).

\subsubsection{Mitochondrial enzymes activities assay}

The succinate dehydrogenase (SDH, EC 1.3.5.1) activity was determined in isolated bivalve mitochondria using a commercially available test kit (MAK197, Sigma-Aldrich). SDH catalyzes the oxidation of succinate to fumarate and carries electrons from FADH to CoQ. SDH activity was determined by generating a product (commercial DCIP) of which absorbance at $600 \mathrm{~nm}$ was proportional to the observed enzymatic activity. SDH activity was expressed in $\mathrm{nmol} / \mathrm{min} / \mathrm{mg}$ of the mitochondrial protein.

The cytochrome c oxidase (COX, EC 1.9.3.1) activity was determined using a commercially available test kit (CYTOCOX1, Sigma-Aldrich). COX is the principal terminal oxidase of high affinity oxygen in the aerobic metabolism of all animals. The activity of COX was measured based on its decrease in absorbance at $550 \mathrm{~nm}$ of ferrocytochrome c caused by its oxidation to ferricytochrome c by cytochrome c oxidase. COX activity was expressed in $\mathrm{nmol} / \mathrm{min} / \mathrm{mg}$ of the mitochondrial protein.

\subsection{Antioxidative and physiological stress biomarkers}

Individual samples were homogenized manually with a Teflon-pestle homogenizer in ice-cold buffer (to obtain 20\% homogenate) containing $50 \mathrm{mM}$ Tris- $\mathrm{H}_{2} \mathrm{SO}_{4}$, pH 7.6 with $0.1 \mathrm{mM}$ EDTA, 1 mM PMSF, 2 $\mathrm{mM}$ DTT and $0.2 \%$ Triton $\mathrm{X}-100$. The homogenates were centrifuged at $14000 \times \mathrm{g}$ for 30 minutes at $4^{\circ} \mathrm{C}$ using Centrifuge SIGMA 3K18. The supernatants were transferred into fresh tubes and used for analysis. Cytosolic protein was determined by Lowry method ${ }^{41}$ with modification of Peterson ${ }^{42}$. 
The TAC (Total Antioxidant Capacity) assay was measured using Total Antioxidant Capacity Assay Kit (MAK187, Sigma-Aldrich). Concentrations of small molecule and protein antioxidants (e.g. tocopherols, carotenes, vitamin A, ubiquinols) were determined using Trolox, a water-soluble vitamin E analog serving as an antioxidant standard. The prepared samples were measured at $570 \mathrm{~nm}$ in Synergy 2 Multi-Mode Reader (BioTek). The amount of TAC was normalized to the protein content of the samples and expressed in $\mathrm{nmol} / \mathrm{mg}$ of total protein concentration.

Acetylcholinesterase (ACHE; EC 3.1.1.7) activity was measured with AChE Activity Assay Kit (MAK119, Sigma-Aldrich). This assay is an optimized version of the Ellman method in which thiocholine, produced by $A C h E$, reacts with 5,5'-dithiobis(2-nitrobenzoic acid) to form an colorimetric product, proportional to the AChE activity present. The absorbance was measured for $10 \mathrm{~min}$ at $412 \mathrm{~nm}$ in Synergy 2 MultiMode Reader (BioTek). AChE activity was expressed in $\mathrm{nmol} / \mathrm{min} / \mathrm{mg}$ of total protein concentration.

Glutathione S-transferase (GST; EC 2.5.1.18) activity was determined spectrophotometrically (UV-VIS Spectrophotometer, Beckman Coulter) by the method of Habig et al. ${ }^{43}$ The reaction mixture contained $100 \mathrm{mM}$ phosphate-buffered saline buffer (pH 6.5), 100 mM 1-chloro-2, 4-dinitrobenzene (CDNB) and the reaction started by adding supernatant and $100 \mathrm{mM}$ glutathione as substrate. The absorbance was measured for $5 \mathrm{~min}$ at $340 \mathrm{~nm}$. GST activity was expressed in $\mathrm{nmol} / \mathrm{min} / \mathrm{mg}$ of total protein concentration.

CBO level was detected using the Protein Carbonyl Content Assay Kit (MAK094, Sigma-Aldrich). Carbonyl content was determined by the derivatization of protein carbonyl groups with 2,4dinitrophenylhydrazine (DNPH) leading to the formation of stable dinitrophenyl (DNP) hydrazone adducts that are proportional to the carbonyls present. Absorbance was measured at $375 \mathrm{~nm}$ in Synergy 2 Multi-Mode Reader (BioTek). The amount of $\mathrm{CBO}$ was normalized to the protein content of the samples and expressed in $\mathrm{nmol} / \mathrm{mg}$ of total protein concentration.

Malondialdehyde (MDA) level was detected using the Lipid Peroxidation (MDA) Assay Kit (MAK085, Sigma-Aldrich) by the reaction of MDA with thiobarbituric acid (TBA) forming amount of colorimetric product proportional to MDA. Samples were pipetted on a 96 - well microplate and absorbance was measured at $532 \mathrm{~nm}$ in Synergy 2 Multi-Mode Reader (BioTek). The amount of MDA was normalized to the samples protein content and expressed in $\mathrm{nmol} / \mathrm{mg}$ of total protein concentration.

\subsection{Determination of corticosteroids in L. balthica tissues}

Corticosteroids concentration was measured according to Jakubowska et al. ${ }^{44}$. Each clam was homogenized using $5 \mathrm{ml}$ of buffer containing $8.5 \mathrm{mM} \mathrm{MgCl}$, $3.13 \mathrm{mM} \mathrm{KCl}, 7.59 \mathrm{mM} \mathrm{NaCl}, 2.7 \mathrm{mM}$ $\mathrm{CaCl}_{2}, 50 \mathrm{mM}$ Tris/HCl, pH 7.4) per tissue gram. Next, MTBE (tert-butyl methyl ether) was added, the 
sample was mixed for $1 \mathrm{~min}$ and the mixture was centrifuged at $3000 \times \mathrm{g}$ for $15 \mathrm{~min}$ at room temperature. The supernatant was transferred to a new glass vial and MTBE was allowed to evaporate to dryness at $45^{\circ} \mathrm{C}$. Upon evaporation, the dry residue of the eluate was dissolved in $100 \mu$ l of methanol and $5 \mu \mathrm{l}$ of this solution was injected into the HPLC-ESI-MS/MS system. The elution was performed under a 10-min gradient. Testosterone-2,3,4- ${ }^{13} \mathrm{C}_{3}$ and 4-Androstene-3,17-dione-2,3,4- ${ }^{13} \mathrm{C}_{3}$ were used as internal standards. HPLC-ESI-MS/MS analysis was performed using a triple-quadrupole mass spectrometer (TSQ Vantage, Thermo Scientific) equipped with an ion electrospray source (ESI) coupled with a HPLC system (Thermo Scientific) using selected reaction monitoring (SRM) for detection in positive ion mode. All analytes were detected in SRM. The columns Kinetex Phenyl-Hexyl $50 \times 2.1 \mathrm{~mm}$ $1.7 \mathrm{u}$ and Kinetex Biphenyl $50 \times 1 \mathrm{~mm} \mathrm{1.7u}$ (Phenomenex) were used. Buffers used for the HPLC gradient elution included buffor A $(0.1 \%$ formic acid in deionized water) and B ( $0.1 \%$ formic acid in methanol). Column equilibration was performed for $10 \mathrm{~min}$. The total analysis time was $10 \mathrm{~min}$. Calibration curves were prepared based on matrix and plotted as the peak area ratio (standard/IS) versus the amount of analytes. Next, the quantity of selected corticosteroids was calculated.

\subsection{Statistical analysis}

The occurrence of statistically significant differences between groups (healthy and neoplastic) was tested using a non-parametric Kruskal-Wallis ANOVA. In all cases the significance was set at $p<0.05$. All statistical analyses were carried out in STATISTICA 13.0 software.

\section{Results}

\subsection{ADA and ALP activities in the haemolymph}

Activities of ADA and ALP measured in haemolymph of healthy and neoplastic clams are presented at the Fig. 2. In both tested groups ADA activity was at a similar level, with slightly lower activity observed in neoplastic clams $(6.2 \pm 2.6 \mathrm{nmol} / \mathrm{min} / \mathrm{mL}$ in healthy and $5.5 \pm 2.1 \mathrm{nmol} / \mathrm{min} / \mathrm{ml}$ in neoplastic clams). A similar pattern was observed in ALP activity $(174.6 \pm 31.3 \mathrm{nmol} / \mathrm{min} / \mathrm{ml}$ in neoplastic and $210.9 \pm$ $50.4 \mathrm{nmol} / \mathrm{min} / \mathrm{ml}$ in healthy clams). No significant differences between both tested groups in ADA and ALP activities were found (Kruskal-Wallis, $\mathrm{p}<0.05$ ).

\subsection{FAA concentration}

In general, nine amino acids were determined in bivalve haemolymph (Tab. 1). Aspartate (Asp) was present at the highest concentration (about $2.7 \mathrm{mM}$ ) and taurine (Tau) was found at the lowest level (about $1.3 \mu \mathrm{M}$ ). Overall, the comparative analysis showed no differences between FAA levels in haemolymph of healthy and neoplastic clams, except for glutamine $(G / n)$, which occurred at a 
significantly higher concentration in clams with neoplasia $(86.6 \mu \mathrm{M})$ compared to the healthy ones $(22.2 \mu \mathrm{M})$.

\subsection{Mitochondrial respiration and mitochondrial enzyme activities}

Coupled mitochondria isolated from neoplastic bivalves were characterised by decreased respiration level when compared to the healthy clams. Mitochondrial oxygen consumption in the presence of succinate, as well as reduced respiratory induction in the presence of ADP, were 3 and 2.5 times lower in neoplastic than in healthy clams, respectively. Additionally, mitochondria isolated from neoplastic bivalves were found to be less sensitive to used inhibitors in comparison to healthy ones (Fig. 3a). Examination of individual components of the respiratory chain in uncoupled mitochondria showed similar activity of respiratory chain proteins in the mitochondria of healthy and neoplastic bivalves, except for complex I, in which the oxygen consumption capacity was significantly higher in healthy clams (Fig. 3b). Sensitivity of respiratory chain complexes to inhibitors such as rotenone, antimycin A and oligomycin was observed in the mitochondria of healthy and neoplastic bivalves. Moreover, the transfer of electrons through ETC to the artificial acceptor ascorbate/TMPD was observed in both clam groups. Mitochondrial SDH activity was low $(3.8 \mathrm{nmol} / \mathrm{min} / \mathrm{mg}$ of protein) and comparable in both groups (Fig. 3c). Mitochondrial cytochrome c oxidase activity was significantly lower in neoplastic individuals (9.06 \pm 3.31 ) in comparison to the healthy ones $(12.9 \pm 2.6 \mathrm{nmol} / \mathrm{min} / \mathrm{mg}$ ) (Fig. 3c).

\subsection{Antioxidative and physiological stress biomarkers}

Low-molecular antioxidant concentration was $171.3 \pm 23.7 \mathrm{nmol} / \mathrm{mg}$ protein in healthy and $218.9 \pm$ $36.1 \mathrm{nmol} / \mathrm{mg}$ protein in neoplastic clams, thus in the latter group the level of antioxidants was significantly higher ( $p=0.028$, Fig. 4a). AChE activity in tissues from healthy and neoplastic clams was at a similar level, $19.7 \pm 5.9$ and $22.8 \pm 8.0 \mathrm{nmol} / \mathrm{min} / \mathrm{mg}$ protein, respectively (Fig. 4b). Also, no statistically significant differences between healthy and neoplastic clams in GST activity were observed $(18.5 \pm 5.9 \mathrm{nmol} / \mathrm{min} / \mathrm{mg}$ protein in healthy and $16.9 \pm 7.9 \mathrm{nmol} / \mathrm{min} / \mathrm{mg}$ protein in neoplastic clams, Fig.4b). No statistically significant differences in the level of accumulation of protein peroxidation (CBO) and lipid peroxidation (MDA) products between healthy and neoplastic bivalves were found. The amount of $\mathrm{CBO}$ in healthy clams was $3.3 \pm 1.6 \mathrm{nmol} / \mathrm{mg}$ protein while in neoplastic clams it was $3.2 \pm$ $1.9 \mathrm{nmol} / \mathrm{mg}$ protein. The amount of MDA in healthy clams was $1.7 \pm 0.4 \mathrm{nmol} / \mathrm{mg}$ protein while in neoplastic cams it was $1.9 \pm 0.67 \mathrm{nmol} / \mathrm{mg}$ protein (Fig. 4c).

\subsection{Corticosteroids}

Corticosterone was found at high concentration in both healthy $(57.2 \pm 25.8 \mathrm{ng} / \mathrm{g} \mathrm{w.w.})$ and neoplastic (53.4 \pm 27.2 ng/g w.w.) clams. Levels of dehydrocorticosterone were lower and comparable between 
both groups $(14.1 \pm 6.2 \mathrm{ng} / \mathrm{g}$ w.w. and $16.4 \pm 4.2 \mathrm{ng} / \mathrm{g}$ w.w. in healthy and neoplastic clams, respectively, Fig. 5a). Cortisol was found at a concentration of $0.95 \pm 0.76 \mathrm{ng} / \mathrm{gram}$ w.w. in healthy clams, and its level was significantly higher in neoplastic clams ( $3.1 \pm 2.4 \mathrm{ng} / \mathrm{g}$ w.w., p=0.005) (Fig. 5b). Cortisone was determined to be at the lowest level of all corticosteroids tested, and its concentration was similar in both tested groups $(0.6 \pm 0.6 \mathrm{ng} / \mathrm{gram}$ w.w. in healthy and $0.6 \pm 0.4 \mathrm{ng} / \mathrm{gram}$ w.w. in neoplastic clams) (Fig. 5b).

\section{Discussion}

The haemocyte neoplasia occurs at a high prevalence in bivalves inhabiting the Gulf of Gdańsk, and the disease specifically affects $L$. balthica clams $^{5,6,45}$. Recently, the transmission of independent cancer lineages between bivalves was discussed as an important factor in environmental carcinogenesis occurring in the marine environments $14,16,17$ and the phenomena may also be responsible for the high frequency of neoplasia in L. balthica. In such cases, genotypes of neoplastic cells are nearly identical, and they do not match those of the solid tissue of the host animal. Indeed, our preliminary data on mtCOXI sequences suggest high similarity between leukemia-like neoplasia cases obtained from different $L$. balthica clams, highlighting the infectious nature of the disease (own data not published). The present work was designed to determine suitable markers of the potentially contagious neoplastic disorder that can help in diagnosis of the neoplasia and increase our knowledge about environmental carcinogenesis. In order to achieve that goal, we characterized various features potentially distinguishing neoplastic cells from normal tissue cells at the biochemical and metabolic levels. As previously stressed, alteration in various enzymatic activities in vertebrate serum have been reported in malignancies such as leukemia ${ }^{20}$, and this data is lacking for neoplastic disorders developing in marine bivalves. Indeed, ADA and ALP activities measured in bivalve haemolymph were selected for this study as these enzymes are commonly used as markers in assessing the progression of various leukemias in higher vertebrates. For example, high levels of ADA activity were found in plasma, erythrocytes, and mononuclear cells from patients with acute leukemia, especially acute lymphoblastic leukemia and blastic crisis of chronic myeloid leukemia ${ }^{24}$. Increased ALP activity with similar properties was found in several human lymphoblastoid cell lines, in chronic lymphatic leukemic cells, in organs of leukemic mice, and in sera of patients with certain lymphoproliferative disorders ${ }^{46}$. Also, both enzymes are participating in various metabolic and developmental processes including the development of inflammatory response and cytokine production ${ }^{47,48}$. Yet, ADA immunological functions are not recognized in bivalves and the data concerning this enzyme only contribute to protein identification and its molecular/kinetic properties ${ }^{23,49}$. ALP was previously detected and characterized in various invertebrate species ${ }^{50-52}$, and it was also used as an immunity variable in clams ${ }^{53}$. In particular, ALP activity changed in response to stressors including various biotic and abiotic factors, pollution or 
infection, and decrease in ALP activity was suggested as one of the indicators of reduced immunocompetence in those animals. Yet, in our study no differences in ADA or ALP activities between healthy and neoplastic clams were observed, highlighting potential occurrence of physiological differences between leukemia found in vertebrates and leukemia-like cancer occurring in L. balthica from the Gulf of Gdańsk.

Marine molluscs have a great ability to regulate haemolymph osmolarity with inorganic solutes and levels of free amino acids. The dominant amino acids in bivalve haemolymph are aspartic acid (or its ionic form aspartate), glutamic acid (or its ionic form glutamate, Glu), Ser, Pro, and Tau, which is typical for marine molluscs ${ }^{32}$. These amino acids may perform two of the most important functions determining physiological functions of osmoconformers: (i) provide ions necessary for the balance of internal cations; and (ii) provide extra solutes necessary for osmoregulation ${ }^{32}$. Additionally, FAAs act as substrates for energy metabolism and protein synthesis. In bivalves, FAA composition may differ at species, population or even at individual levels ${ }^{34,54,55}$. These differences are related to factors such as sex, gametogenesis stage, nutritional status ${ }^{33,34}$ or may be regarded as indicators of stress ${ }^{55,56}$. FAA profile and concentration in clams was also proven to be tissue-dependent ${ }^{57,58}$. Our results indicated the presence of nine free amino acids in L. balthica haemolymph; Asp, Glu, Pro, Ser, Ala, Gln, Gly, Tau and 5-hydroxylysine with the latter beeing an elementary part of collagen ${ }^{59}$. According to Sokołowski et al. ${ }^{34}$, overall 14 amino acids were detected in L. balthica tissues (the whole body) with Ala, Gln, Arg, Gly and Orn composing over $80 \%$ of the total FAAs. In our study, Asp, Glu, Pro, Ser and Ala constituted of over $90 \%$ of total FAA in the haemolymph of both healthy and neoplastic clams. Performed comparative analyses indicated no significant differences in the amount of FAAs between healthy and neoplastic clams except for Gln, which level was significantly higher in neoplastic individuals. Gln is a key amino acid, and its amount also increases in various types of mammalian cancers, including human cancers. Gln metabolism contributes to energy production, macromolecular synthesis, and redox homeostasis, and is essential for survival of some cancer cells as they are highly dependent on GIn for glutaminolysis ${ }^{60}$. The major function of glutaminolysis is to supply intermediary metabolites in the TCA (Krebs) cycle for cell growth. In the haemolymph of neoplastic bivalves, GIn may have a similar function as in vertebrate serum, as it acts as the main substrate for intensively proliferating cells such as hemocytes. Indeed, according to our results disseminated neoplasia is a condition affecting GIn level in the haemolymph, and its increased concentration in the leukemic clams is most likely related to the pathology of the disease (e.g. inhibition of glutaminase involved in Gln catabolism or its increased synthesis) ${ }^{61,62}$. On the cellular level, however, as cancer cells need to adapt to increased biosynthetic activity, an increased Gln concentration plays an essential role in energy production, possibly via glutaminolysis ${ }^{60,63}$. This result also find $\mathrm{Gln}$ as a usefull marker of environmental cancerogenesis of 
potential infectious nature. Also, a relatively high level of Asp in the hemolymph of L. balthica and a concomitant absence of asparagine were documented. This may indicate the presence of an enzyme with asparaginase activity that breaks down the available asparagine. So far, active asparaginase was only found in Aeromonas bacteria possibly forming symbiotic relationships with bivalves ${ }^{64}$. Our results show that healthy and neoplastic clams maintained high levels of Asp in the haemolymph, showing no differences in the potential activity of asparaginase-like enzymes in both clam groups.

The metabolic pathways of vertebrate cancer cells are examined at various levels but the knowledge about metabolic pathway of leukemia-like cells present in bivalves is lacking. Normal cells obtain energy through aerobic respiration but solid tumor cells prefer to obtain energy through anaerobic mechanisms. In various neoplastic disorders, cells convert glucose by fermentation into lactate even with sufficient oxygen availability. Only a small amount of pyruvate is used for oxygen respiration leading to the commonly known Warburg effect. The lactate in cancer cells is not only synthesized from glucose, but it may also be formed from Gln during glutaminolysis ${ }^{65}$. The Warburg effect may also result from mitochondrial dysfunction caused by mutations within the mtDNA ${ }^{31,66}$. Yet, most of the available information on glucose metabolism in cancer cells comes from solid tumors. Changes in signal pathways and morphology occurring in leukemic cells may resemble activation of normal lymphocytes. Indeed, as described above, higher levels of Gln were also detected in neoplastic $L$. balthica clams. Performed functional analyses of mitochondria isolated from healthy and neoplastic clams highlighted that in coupled mitochondria, despite the availability of respiratory substrates such as pyruvate, malate and succinate, oxygen consumption was three times lower when compared to healthy mussels. Furthermore, in uncoupled mitochondria lower oxygen consumption by respiratory complex I was observed in clams affected by the leukemia-like cancer. Altered mitochondrial function is a hallmark of many cancers, although the nature of functional modification depends on the type of cancer ${ }^{67,68}$. For example, mutations in complex I subunit ND6 increased the metastatic potential by producing excessive ROS, whereas an ND5 mutation promoted tumorigenesis by oxidative stress and Akt-kinase activation $^{69,70}$. Also, in the $\mathrm{L} 1210$ cancer cell line that were previously injured by cytotoxic macrophages the respiratory oxygen chain was inhibited at complexes I and $\|^{71}$.

As an occurring Warburg effect reduces effectiveness of mitochodrial respiration and switches on anaerobic metabolism, we measured activities of succinate dehydrogenase (SDH) and cytochrome c oxidase (COX) in healthy and neoplastic bivalves. SDH is a mitochondrial enzyme that catalyzes the oxidation of succinate to fumarate and carries electrons from FADH to CoQ in electron transport chain. It has a central function in the maintenance of cellular energy metabolism via the Krebs (tricarboxylic acid) cycle and the ETC. Our results indicate that the activity of mitochodrial SDH was low and there was no difference between SDH activity in healthy and neoplastic bivalves. Cytochrome C oxidase 
(COX) is the principal terminal oxidase of high affinity oxygen in the aerobic metabolism of all animals, plants, yeasts, and some bacteria. The enzyme is present in mitochondria and is probably unique in providing energy by coupling electron transport through the cytochrome chain with oxidative phosphorylation. Indeed, in clams with neoplasia, activity of COX was significantly lower than in healthy molluscs. This may confirm the impaired mitochondrial respiration in neoplastic clams. Decreased COX activity may be a consequence of occurring mtDNA mutations in the neoplastic cells, but may also result after changes in the non-cancer clam tissues. It is worth noting that the structure and function of COX are affected in a wide variety of human diseases including cancer ${ }^{72}$. Mainly, dysfunctional COX promotes oxidative stress induced by superoxide elevation and ATP depletion ${ }^{73}$.

Many cancers arise from infection or inflammation ${ }^{74}$. Recent data have expanded the concept that inflammation is a critical component of neoplasia in vertebrates ${ }^{75,76}$. Invertebrate immunity is based on the innate immune system, in which hemocytes are the first line of defense against any of the external and internal assaults, playing a major role in both humoral and cellular immunity. Haemocytes as well as other immune cells present in haemolymph produce various cytokines such as IL- $\alpha$ and $\beta$, IL2, IL-6-like and TNF- $\alpha$-like molecules ${ }^{77,78}$. Phagocytes, sometimes containing brown pigmentation (lipofuscin or melanin), are involved in the processes such as phagocytosis, melanisation and lysosomal digestion. Lipofuscin, yellow-brown pigment granules containing lipids, sugars, metals and oxidised proteins, is an end product formed during oxidative stress found in lysosomes. Melanization, a process leading to melanin formation, is controlled by strictly regulated phenoloxidase (PO) activity (pro-PO activating system), as in uncontrolled conditions excessive production of ROS occur ${ }^{79,80}$. Also, macrophages induce the generation of reactive oxygen species (ROS) within tumor cells through secretion of various factors, such as cytokines or TNF- $\alpha{ }^{81}$. Production of ROS by neutrophils and macrophages as a mechanism to kill tumor cells is well established. In these cells, a rapid burst of superoxide formation primarily mediated by NAPDH oxidase leads to subsequent production of hydrogen peroxide ${ }^{82,83}$. Furthermore, during inflammatory reactions, activated macrophages also generate nitric oxide, which reacts with superoxide to produce peroxinitrite radicals that are similar in their activity to hydroxyl radicals and contribute to tumor cell apoptosis ${ }^{84}$. Thus, elevated rates of ROS have been detected in almost all cancers, where they promote many aspects of its development and progression. However, cancer cells also express increased levels of antioxidant proteins, suggesting that a delicate balance of intracellular ROS levels is required for cancer cell function, as increased levels of low-molecular antioxidants (tocopherols, carotenes, ubiquinols, glutathione and ascorbate) correspond to the rising ROS concentrations. It was thus expected that ROS levels would be higher in neoplastic clams than in healthy ones. Indeed, significantly higher concentrations of antioxidants was observed in neoplastic bivalves when compared to the healthy ones. However, an increased amount 
of oxidative stress products (MDA and $\mathrm{CBO}$ ) was not found, suggesting an efficient antioxidant response in neoplastic clams. Also, GST activity, playing a critical role in cellular detoxification against xenobiotics and noxious compounds as well as against oxidative stress, did not differ between healthy and neoplastic L. balthica. Similarly, individuals with neoplasia showed no visual signs of neurotoxicity, as AChE activity was at the same level as in healthy mussels.

We, for the first time, demonstrated the content of various corticosteroids in healthy and neoplastic L. balthica. Our results highlighted high levels of corticosterone and lower amounts of dehydrocorticosterone, cortisol and cortisone present in normal bivalve tissues. In vertebrates, the brain and immune systems are linked by two primary pathways: (i) the sympathoadrenal system (SAS), via either direct neural innervation of lymphoid tissue or catecholamine (e.g. epinephrine, norepinephrine) release from the adrenal medulla and (ii) the hypothalamo-pituitary- adrenal (HPA) axis and subsequent release of glucocorticoids (e.g. cortisol, corticosterone) from the adrenal cortex 85. Analogous neuro-endocrine-immune connections can also be found in invertebrates and multiple neuro-endocrine systems can modulate immune function ${ }^{86}$. In molluscs, hemocytes are the main source of adrenocorticotropic hormone (ACTH), corticotropin-releasing hormone ( $\mathrm{CRH}$ ) and biogenic amines (e.g. serotonin, octopamine, adrenalin) ${ }^{27,28}$. In most species, cortisol regulates not only metabolism, but also immune response, and its release takes place during an organism response to stress ${ }^{87,88}$. In molluscs, the presence of cortisol has long been described ${ }^{88,89}$ but its origin and genomic mechanism of action is unknown, as no corticosteroid receptors have been found so far. The nongenomic effect of corticosteroids in vertebrates may affect the signaling pathways of MAPK kinases, adenylyl cyclase, protein kinase C (PKC), and G-proteins ${ }^{90}$, and this interaction could be similar in bivalve molluscs. We here observed a significant increase in cortisol level in the neoplastic individuals that may result from activation of the clams' immune systems, and in particular hemocytic activation. However, such an increase can also be a consequence of massive changes occurring in hemocytes at structural, morphological and genetic levels due to spreading leukemia-like neoplastic disorder. As a result, an increase in the ability of antigens to induce the increase of ACTH and CRH levels in haemolymph and the rise of synthesis of corticosteroids, mainly cortisol, can be expected. Indeed, available data on mammals highlight a correlation between an increase in blood cortisol level and the occurrence of cancer, including acute myeloid leukemia ${ }^{91,92}$. Nevertheless, there are no other available data linking the levels of corticosteroids with the progression of disseminated neoplasia in marine bivalves. An enhanced knowledge about the MoA (mechanism of action) of cortisol in molluscs would therefore allow a broader understanding of the function of steroid hormones in invertebrates in general and of cortisol in particular, and of its role in neoplastic disorders occurring in marine bivalves. 
Yet, bivalve endocrinology is deeply underresearched and there are various gaps in the knowledge to be filled in order to fully understand the processes behind environmental carcinogenesis.

\section{Conclusions:}

Haemic neoplasia is a disease of unknown biochemical characteristics that occur in various marine invertebrates. To increase our knowledge about this phenomena, we characterised selected enzymatic activities and FAA levels in bivalve haemolyph, measured corticosteroids levels, characterised antioxidative and physiological stress biomarkers response in clam tissue and measured mitochondrial respiration in neoplastic and healthy cells. Performed comparative analyses showed no differences in ADA and ALP activities between healthy and neoplastic clams. In both clam groups nine FAAs were found (Asp, Glu, Pro, Ser, Ala, Gln, Gly, Tau and 5-hydroxylysine) but in the neoplastic clams significantly higher content of GIn was observed when compared to the healthy ones. Such high levels of Gln suggest its essential role in energy production in leukemia-like cancer and stresses a potential role of Gln as a marker of environmental carcinogenesis. Analyses of the respiratory pathway highlighted significantly lower oxygen consumption in coupled and uncoupled mitochondria (respiratory complex I) isolated from neoplastic clams that indicated altered mitochondrial function in leukemia-like neoplasia. As an occurring Warburg effect reduces effectiveness of mitochodrial respiration, a switch to anaerobic metabolism and glutaminolysis was expected. Indeed, significantly lower cytochrome c oxidase activity was found in the neoplastic clams, potentially confirming their impaired mitochondrial respiration, and detectable activity of succinate dehydrogenase suggested the occurrence of aerobic metabolism. Indeed, an increased level of Gln highlights glutaminolysis as a potential energy source for cancer cells. Also, a significantly higher concentration of low molecular weight antioxidants level was confirmed in neoplastic clams when compared to the healthy ones, but no elevated oxidative stress markers (MDA and CBO levels and GST activity) were found, suggesting an efficient antioxidant response. Finally, high levels of corticosterone and lower amounts of dehydrocorticosterone, cortisol and cortisone were present in healthy bivalves, while in the neoplastic ones significantly elevated level of cortisol was found. As bivalve hemocytes belong to the main neuroendocrine secretion systems, these changes may be explained by hemocytic activation and/or massive changes occurring in this neoplastic disorder.

\section{Acknowledgements}

The analyses performed within this study were financed by the Harmonia grant 2017/26/M/NZ8/00478 from the Polish Ministry of Science and Higher Education. We would also like to thank dr. Michael Metzger from the Pacific Northwest Research Institute (Seattle, U.S.A.) for reviewing and commenting on the manuscript and language correction. 


\section{Author contribution}

$A H$ - conceptualisation, analysis, data acquiring and interpretation, writing the original draft $A M$ - field sampling, analysis, data acquiring and interpretation, manuscript reviewing and editing $A C$ - analysis and data acquiring $M L$ - analysis and data acquiring $K S$ - funds provider, field sampling, analysis, data interpretation, manuscript writing, reviewing and editing

\section{References:}

1. Kitsoulis, C.V., Baxevanis, A.D. \& Abatzopoulos, T.J. The occurrence of cancer in vertebrates: a mini review. J of Biol Res-Thessaloniki 27, 9 (2020).

2. Díaz, S., Renault, T., Villalba, A. \& Carballal, M. Disseminated neoplasia in cockles Cerastoderma edule: ultrastructural characterisation and effects on haemolymph cell parameters. Dis Aquat Organ 96, 157-167 (2011).

3. Gombač, M., Sitar, R., Pogačnik, M., Arzul, I. \& Jenčič, V. Haemocytic neoplasia in Mediterranean mussels (Mytilus galloprovincialis) in the Slovene Adriatic Sea. Mar Freshw Behav Physiol 46, 135-143 (2013).

4. Barber, B. J. Neoplastic diseases of commercially important marine bivalves. Aquat Living Resour 17, 449-466 (2004).

5. Smolarz, K., Renault, T., Soletchnik, P. \& Wolowicz, M. Neoplasia detection in Macoma balthica from the Gulf of Gdansk: Comparison of flow cytometry, histology and chromosome analysis. Dis Aquat Organ 65, 187-195 (2005).

6. Smolarz, K., Renault, T., Soletchnik, P., \& Wołowicz, M. Survey for neoplasia in Macoma balthica from the Gulf of Gdansk using flow cytometry. Dis Aquat Organ 66, 41-46 (2005).

7. Arriagada, G. Metzger, M., Muttray, A., Sherry, J., Reinisch, C., Street, C., Lipkin, W. \& Goff, S. Activation of transcription and retrotransposition of a novel retroelement, Steamer, in neoplastic hemocytes of the mollusk Mya arenaria. PNAS USA 111, 1417514180 (2014).

8. Walker, C., Böttger, S. A. \& Low, B. Mortalin-based cytoplasmic sequestration of p53 in a nonmammalian cancer model. Am J Pathol 168, 1526-1530 (2006).

9. Walker, C. W. Böttger, S. A., Mulkern, J., Jerszyk, E., Litvaitis, M.\& Lesseret M. Mass culture and characterization of tumor cells from a naturally occurring invertebrate cancer model: applications for human and animal disease and environmental health. Biol. Bull. 216, 23-39 (2009).

10. Aguilera, F. Ukraintseva, S. V. \& Yashin, A. I. Neoplasia in Mollusks: What Does it Tell us about Cancer in Humans? Nat Rev Cancer 5, 807-19 (2005). 
11. Pariseau, J. Saint-Louis, R., Delaport, M., Mohammed Abo El Khair , M., McKenna, P., Tremblay, R., Davidson, T. J., Pelletier, E.\& Berthe, F. C. J. Potential link between exposure to fungicides chlorothalonil and mancozeb and haemic neoplasia development in the soft-shell clam Mya arenaria: A laboratory experiment. Mar Pollut Bull 58, 503-514 (2009).

12. Sunila, I. \& LaBanca, J. Apoptosis in the pathogenesis of infectious diseases of the eastern oyster Crassostrea virginica. Dis Aquat Organ 56, 163-170 (2003).

13. Wołowicz, M., Smolarz, K. \& Sokołowski, A. Neoplasia in Estuarine Bivalves: Effect of Feeding Behaviour and Pollution in the Gulf of Gdansk (Baltic Sea, Poland). in The Comparative Roles of Suspension-Feeders in Ecosystems 165-182 (Springer-Verlag, 2005).

14. Mateo, D. R., MacCallum, G. S. \& Davidson, J. Field and laboratory transmission studies of haemic neoplasia in the soft-shell clam, Mya arenaria , from Atlantic Canada. J Fish Dis 39, 913-927 (2016).

15. Elston, R. A., Kent, M. L. \& Drum, A. S. Progression, lethality and remission of hemic neoplasia in the bay mussel Mytilus edulis. Dis Aquat Organ 4, 135-142 (1988).

16. Metzger, M. J., Reinisch, C., Sherry, J. \& Goff, S. P. Horizontal transmission of clonal cancer cells causes leukemia in soft-shell clams. Cell 161, 255-263 (2015).

17. Metzger, M. J., Villalba, A., Carballal, M. J., Iglesias, D., Sherry, J., Reinisch, C., Muttray, A.F., Baldwin S. A. \& Goff, S. P. Widespread transmission of independent cancer lineages within multiple bivalve species. Nature 534, 705-709 (2016).

18. Carella, F., de Vico, G. \& Landini, G. Nuclear morphometry and ploidy of normal and neoplastic haemocytes in mussels. PLOS ONE 12, e0173219 (2017).

19. Donaghy, L., Jauzein, C. \& Volety, A. K. First report of severe hemocytopenia and immunodepression in the sunray venus clam, Macrocallista nimbosa, a potential new aquaculture species in Florida. Aquaculture 364-365, 247-251 (2012).

20. Ghaderi, B., Amini, S., Maroofi, F., Jalali, C., Javanmardi, M., Roshani, D., \& Abdi, M. Adenosine deaminase activity in chronic lymphocytic leukemia and healthy subjects. Int J Cancer Manag 9, 1-6 (2016).

21. Stokol, T., Schaefer, D. M., Shuman, M., Belcher, N. \& Dong, L. Alkaline phosphatase is a useful cytochemical marker for the diagnosis of acute myelomonocytic and monocytic leukemia in the dog. Vet Clin Pathol 44, 79-93 (2015).

22. Cristalli, G. Costanzi, S., Lambertucci, C., Lupidi, G., Vittori, S., Volpini, R. \& Camaioni E. Adenosine deaminase: Functional implications and different classes of inhibitors. Med Res Rev 21, 105-128 (2001).

23. Chen, Y.-X., Uchida, H., Migitaka, Y., Hayashi, T. \& Uwajima, T. Isolation and characterization of adenosine deaminase in the adductor muscle of marine bivalve molluscs. Fish Sci 66, 748-754 (2000).

24. Morisaki, T., Fujii, H. \& Miwa, S. Adenosine deaminase (ADA) in leukemia: clinical value of plasma ADA activity and characterization of leukemic cell ADA. Am J Hematol 19, 37-45(1985). 
25. Demas, G. E., Adamo, S. A. \& French, S. S. Neuroendocrine-immune crosstalk in vertebrates and invertebrates: implications for host defence. Funct Ecol 25, 29-39 (2011).

26. Smith, L. K. \& Cidlowski, J. A. Glucocorticoid-induced apoptosis of healthy and malignant lymphocytes. Prog Brain Res 182, 1-30 (2010).

27. Dahl, E., Falck, B., von Mecklenburg, C., Myhrberg, H. \& Rosengren, E. Neuronal localization of dopamine and 5-Hydroxytryptamine in some mollusca. Z Zellforsch Mik Ana 71, 489-498 (1966).

28. Sweeney, D. C. The anatomical distribution of monoamines in a fresh-water bivalve mollusc, Sphaerium sulcatum (L.). Comp Biochem Phys A 25, 601-613 (1968).

29. Weinberg, F. \& Chandel, N. S. Reactive oxygen species-dependent signaling regulates cancer. Cell Mol Life Sci 66, 3663-3673 (2009).

30. Galluzzi, L., Kepp, O., Heiden, M. G. V. \& Kroemer, G. Metabolic targets for cancer therapy. Nat Rev Drug Discov 12, 829-846 (2013).

31. Maiuri, M. C. \& Kroemer, G. Essential role for oxidative phosphorylation in cancer progression. Cell Metab 21, 11-12 (2015).

32. Zurburg, W. \& de Zwaan, A. The role of amino acids in anaerobiosis and osmoregulation in bivalves. J Exp Zool 215, 315-325 (1981).

33. Kube, S., Sokolowski, A., Jansen, J. M. \& Schiedek, D. Seasonal variability of free amino acids in two marine bivalves, Macoma balthica and Mytilus spp., in relation to environmental and physiological factors. Comp Biochem Phys A 147, 1015-1027 (2007).

34. Sokolowski, A., Wolowicz, M. \& Hummel, H. Free amino acids in the clam Macoma balthica L. (Bivalvia, Mollusca) from brackish waters of the southern Baltic Sea. Comp Biochem Phys A 134, 579-592 (2003).

35. Rudman, D., Vogler, W. R., Howard, C. H. \& Gerron, G. G. Observations on the plasma amino acids of patients with acute leukemia. Cancer Res 31, 1159-1165 (1971).

36. Muscaritoli, M., Conversano, L., Petti, M. C., Torelli, G. F., Cascino, A., Mecarocci, S., Annicchiarico, M. A.\& Fanelli, F. R. Plasma amino acid concentrations in patients with acute myelogenous leukemia. Nutrition 15, 195-199 (1999).

37. Smolenski, R. T., Lachno, D. R., Ledingham, S. J. M. \& Yacoub, M. H. Note Determination of sixteen nucleotides, nucleosides and bases using high-performance liquid chromatography and its application to the study of purine metabolism in hearts for transplantation. J Chromatogr A 527, 414-420 (1990).

38. Olkowicz, M., Debski, J., Jablonska, P., Dadlez, M. \& Smolenski, R. T. Application of a new procedure for liquid chromatography/mass spectrometry profiling of plasma amino acid-related metabolites and untargeted shotgun proteomics to identify mechanisms and biomarkers of calcific aortic stenosis. J Chromatogr A 1517, 66-78 (2017). 
39. Schnaitman, C. \& Greenawalt, J. W. Enzymatic properties of the inner and outer membranes of rat liver mitochondria. J Cell Biol 38, 158-175 (1968).

40. Walker, J. M., Hammond, J. B. W. \& Kruger, N. J. The Bradford method for protein quantitation. in New Protein Techniques 25-32 (Humana Press, 2003).

41. Lowry, O. H., Rosenbrough, N. J., Farr, A. L. \& RandallL, R. J. Protein measurement with the Folin phenol reagent. J Biol Chem 193, 265-75 (1951).

42. Peterson, G. L. A simplification of the protein assay method of Lowry et al. which is more generally applicable. Anal Biochem 83, 346-356 (1977).

43. Habig, W. H., Pabst, M. J. \& Jakoby, W. B. Glutathione S-transferases. The first enzymatic step in mercapturic acid formation. J Biol Chem 249, 7130-7139 (1974).

44. Jakubowska, M., Białowąs, M., Stankevičiūtė, M., Chomiczewska, A., Pažusienė, J., Jonko-Sobuśa, K., Hallmann, A.\& Urban-Malinga, B. Effects of chronic exposure to microplastics of different polymer types on early life stages of sea trout Salmo trutta. Sci Total Environ 740, 139922 (2020).

45. Smolarz, K., Renault, T. \& Wołowicz, M. Ultrastructural study of neoplastic cells in Macoma balthica (Bivalvia) from the Gulf of Gdansk (Poland). J Invertebr Pathol 92, 79-84 (2006)

46. Neumann, H., Kleint, E., Hauck-Granoth, R., Yachnint, S. \& Ben-Bassat, H. Comparative study of alkaline phosphatase activity in lymphocytes, mitogen-induced blasts, lymphoblastoid cell lines, acute myeloid leukemia, and chronic lymphatic leukemia cells. PNAS 73, 1432-1436 (1976).

47. Thuillier, L., Garreau, F. \& Cartier, P. Inability of immunocompetent thymocytes to produce T-cell growth factor under adenosine deaminase deficiency conditions. Cellular Immunology 63, 81-90 (1981).

48. Hirschhorn, R. Adenosine deaminase deficiency. Immunodefic Rev 2, 175-198 (1990).

49. Sato, Y. \& Aikawa, T. Adenosine deaminase in the adductor muscle of the scallop, Patinopecten yessoensis. Comp Biochem Physiol B 99, 221-232 (1991).

50. Blasco, J., Puppo, J. \& Sarasquete, M. C. Acid and alkaline phosphatase activities in the clam Ruditapes philippinarum. Mar Biol 115, 113-118 (1993).

51. Cima, F., Matozzo, V., Marin, M. G. \& Ballarin, L. Haemocytes of the clam Tapes philippinarum (Adams \& Reeve, 1850): morphofunctional characterisation. Fish Shellfish Immunol 10, 677-693 (2000).

52. Mazorra, M. T., Rubio, J. A. \& Blasco, J. Acid and alkaline phosphatase activities in the clam Scrobicularia plana: Kinetic characteristics and effects of heavy metals. Comp Biochem Physiol B 131, 241-249 (2002).

53. Mansour, C., Guardiola, F. A., Esteban, M. Á. \& Mosbahi, D. S. Combination of polycyclic aromatic hydrocarbons and temperature exposure: In vitro effects on immune response of European clam (Ruditapes decussatus). Fish Shellfish Immunol 67, 110-118 (2017). 
54. Baptista, M. Repolho, T., Maulvault, A. L., Lopes, V. M., Narciso, L., Marques, A., Bandarra, N. \& Rosa, R. Temporal dynamics of amino and fatty acid composition in the razor clam Ensis siliqua (Mollusca: Bivalvia). Helgoland Marine Research 68, 465-482 (2014).

55. Chen, D. W. Su, J., Liu, X. L., Guangxi, N., China, P. R., Yan, D. M., Lin, Y., Jiang W. M., \& Chen, X. H. Amino acid profiles of bivalve mollusks from Beibu Gulf, China. J Aquat Food Prod Technol 21, 369-379 (2012).

56. Hummel, H. Amiard-Triquet, C., Bachelet, G., Desprez, M., Marchande, J., Sylvand, B., Amiard, C., Rybarczyk, H., Bogaards, R. H., Sinkea, J. \& de Wolf, L. Free amino acids as a biochemical indicator of stress in the estuarine bivalve Macoma balthica. Sci Total Environ 188, 233-241 (1996).

57. Felbeck, H. \& Wiley, S. Free D-amino acids in the tissues of marine bivalves. Biol Bull 173, 252-259 (1987).

58. Tabakaeva, O. v. \& Tabakaev, A. v. Amino-acid composition of soft tissues of the fareast bivalve mollusk Anadara broughtonii. Chem Nat Compd 52, 468-471 (2016).

59. Haider, F., Falfushynska, H. I., Timm, S. \& Sokolova, I. M. Effects of hypoxia and reoxygenation on intermediary metabolite homeostasis of marine bivalves Mytilus edulis and Crassostrea gigas. Comp Biochem Physiol A 242, (2020).

60. Yang, L., Venneti, S. \& Nagrath, D. Glutaminolysis: A Hallmark of Cancer Metabolism. Annu. Rev. Biomed. Eng 19, 163-194 (2017).

61. Jacque, N., Ronchetti, A. M., Larrue, C., Meunier, G., Birsen, R., Willems, L., Saland, E., Decroocq, J., Maciel, T. T., Lambert, M., Poulain, L., Hospital, M. A., Sujobert, P., Joseph, L., Chapuis, N., Lacombe, C., 5, Moura, I. C., Demo, S., Sarry, J. E., Recher, C., Mayeux, P., Tamburini, J.\& Bouscary, D. Targeting glutaminolysis has antileukemic activity in acute myeloid leukemia and synergizes with BCL-2 inhibition. Blood 126, 1346-1356 (2015).

62. Matre, P., Velez, J., Jacamo, R., Qi, Y., Su, X., Cai, T., Chan, S. M., Lodi, A., Sweeney, S. R., Ma, H., Davis, R. E., Baran, N., Haferlach, T., Xiaohua Su, X., Flores, E. R., 7, Gonzalez, D., Konoplev, S., Samudio, I., DiNardo, C., Majeti, R., Schimmer, A. D., Li, W., Wang, T., Tiziani, S.\& Konopleva, M. Inhibiting glutaminase in acute myeloid leukemia: metabolic dependency of selected AML subtypes. Oncotarget 7, 79722-79735 (2016).

63. Willems, L., Jacque, N., Jacquel, A, Neveux, N., Maciel, T. T., Lambert, M., Schmitt, A., Poulain, L., Green, A. S., Uzunov, M., Kosmider, O., Radford-Weiss, I., Moura, I. C., Auberger, P., Ifrah, N., Bardet, V., Chapuis, N., Lacombe, C., Mayeux, P., Tamburini, J.\& Bouscary, D. Inhibiting glutamine uptake represents an attractive new strategy for treating acute myeloid leukemia. Blood 122, 3521-3532 (2013).

64. Pattnaik, S., Kabi, R., Janaki Ram, K. \& Bhanot, K. K. L-Asparaginase activity in Aeromonas sp. isolated from freshwater mussel. Indian J Exp Biol 38, 1143-1146 (2000).

65. Otto-Ślusarczyk, D., Graboń, W. \& Mielczarek-Puta, M. Aspartate aminotransferasekey enzyme in the human systemic metabolism. Postepy Hig Med Dosw 70, 219-230 (2016). 
66. Czarnecka, A. M., Golik, P. \& Bartnik, E. Mitochondrial DNA mutations in human neoplasia. J Appl Genet 47, 67-78 (2006).

67. Brandon, M., Baldi, P. \& Wallace, D. C. Mitochondrial mutations in cancer. Oncogene 25, 4647-4662 (2006).

68. Chatterjee, A., Mambo, E. \& Sidransky, D. Mitochondrial DNA mutations in human cancer. Oncogene 25, 4663-4674 (2006).

69. Sharma, L. K., Fang, H., Liu, J., Vartak, R., Deng, J. \& Bai, Y. Mitochondrial respiratory complex I dysfunction promotes tumorigenesis through ROS alteration and AKT activation. Hum Mol Genet 20, 4605-4616 (2011).

70. Ishikawa, K., Takenaga, K., Akimoto, M., Koshikawa, N., Yamaguchi, A., Imanishi, H., Nakada, K., Honma, Y. \& Hayashi J. ROS-generating mitochondrial DNA mutations can regulate tumor cell metastasis. Science 320, 661-664 (2008).

71. Granger, D. \& Lehninger, A. Sites of mitochondrial electron transport inhibition in macrophage-injured neoplastic cells. J Cell Biol 95, 527-535 (1982).

72. Srinivasan, S. \& Avadhani, N. G. Cytochrome c oxidase dysfunction in oxidative stress. Free Radic Biol Med 53, 1252-1263 (2012).

73. Sen, S., Kawahara, B. \& Chaudhuri, G. Mitochondrial-associated nitric oxide synthase activity inhibits cytochrome c oxidase: Implications for breast Cancer. Free Radic Biol Med 57, 210-220 (2013).

74. Liou, G. Y. \& Storz, P. Reactive oxygen species in cancer. Free Radic Res 44, 479-496 (2010).

75. Berasain, C., Castillo, J., Perugorria, M. J., Latasa, M. U., Prieto, J.\& Avila, M. A. Inflammation and liver cancer: new molecular links. Ann N Y Acad Sci 1155, 206-221 (2009).

76. Xiao, H. \& Yang, C. S. Combination regimen with statins and NSAIDs: a promising strategy for cancer chemoprevention. Int J Cancer 123, 983-990 (2008).

77. Ottaviani, E., Franchini, A. \& Franceschi, C. Presence of several cytokine-like molecules in molluscan hemocytes. Biochem Biophys Res Commun 195, 984-988 (1993).

78. Cooper, E. L., Arizza, V., Cammarata, M., Pellerito, L. \& Parrinello, N. Tributyltin affects phagocytic activity of Ciona intestinalis hemocytes. Comp Biochem Physiol C 112, 285289 (1995).

79. Cerenius, L. \& Soderhall, K. The prophenoloxidase-activating system in invertebrates. Immunol Rev 198, 116-126 (2004).

80. Luna-González, A., Maeda-Martínez, A. N., Vargas-Albores, F., Ascencio-Valle, F. \& Robles-Mungaray, M. Phenoloxidase activity in larval and juvenile homogenates and adult plasma and haemocytes of bivalve molluscs. Fish Shellfish Immunol 15, 275-282 (2003).

81. Storz, P. Reactive oxygen species in tumor progression. Front Biosci 10, 1881-1896 (2005). 
82. Babior, B. M. The respiratory burst oxidase. Hematol Oncol Clin North Am 2, 201-212 (1988).

83. Segal, A. W. \& Shatwell, K. P. The NADPH oxidase of phagocytic leukocytes. Ann N Y Acad Sci 832, 215-222 (1997).

84. Cui, S., Reichner, J. S., Mateo, R. B. \& Albina, J. E. Activated murine macrophages induce apoptosis in tumor cells through nitric oxide-dependent or -independent mechanisms. Cancer Res 54, (1994).

85. Demas, G. E., Adamo, S. A. \& French, S. S. Neuroendocrine-immune crosstalk in vertebrates and invertebrates: Implications for host defence. Funct Ecol 25, 29-39 (2011).

86. Adamo, S. A. Comparative psychoneuroimmunology: evidence from the insects. Behav Cogn Neurosci Rev 5, 128-140 (2006).

87. Boland, R., Joyce, B. J., Wallace, M. J., Stanton, H., Fosang, A. J., Pierce, R. A., Harding, R.\& Hooper, S. B. Cortisol enhances structural maturation of the hypoplastic fetal lung in sheep. J Physiol 554, 505-517 (2004).

88. Binder, A. R. D., Pfaffl, M. W., Hiltwein, F., JuergenGeis, J. \& Beggel, S. Does environmental stress affect cortisol biodistribution in freshwater mussels? Conserv Physiol 7, coz101 (2019)

89. Lupo, C., Prisco, D. I., Dessi' Fulgheri, F. \& Tomasucci, M. Identification and biosynthesis of steroids in the marine mollusc Aplysia depilans. Comp Biochem Physiol 45, 303-310 (1973).

90. Lee, S. R., Kim, H. K., Youm, J. B., Dizon, L. A., Song, I. S., Jeong, S. H., Seo, D. Y., Ko, K. S., Rhee, B. D., Kim, N. \& Han, J. Non-genomic effect of glucocorticoids on cardiovascular system. Pflugers Arch 464, 549-559 (2012).

91. Behrend, E. N., Kemppainen, R. J., Boozer, A. L., Whitley, E. M., Smith, A. N.\& Buschet, K. A. Serum 17- $\alpha \alpha$-hydroxyprogesterone and corticosterone concentrations in dogs with nonadrenal neoplasia and dogs with suspected hyperadrenocorticism. J Am Vet Med Assoc 227, 1762-1767 (2005).

92. Rasmuson, T., Ljungberg, B., Grankvist, K., Jacobsen, J. \& Olsson, T. Increased serum cortisol levels are associated with high tumour grade in patients with renal cell carcinoma. Acta Oncol 40, 83-87 (2001). 
Table 1. Concentrations of FAAs $(\mu \mathrm{M})$ detected in haemolymph of healthy and neoplastic clams. Data are presented as mean \pm S.E.M. Asterisk indicate significant differences between healthy $(n=12)$ and neoplastic $(n=11)$ clams (Kruskal Wallis ANOVA, $p<0.05)$.

\begin{tabular}{|l|l|l|l|}
\hline FAAs concentration $(\boldsymbol{\mu M})$ & healthy clams & neoplastic clams & $\boldsymbol{p}$ \\
\hline Aspartate/Asp & $2765,4 \pm 653,86$ & $2653,3 \pm 395,94$ & 0,643 \\
\hline Glutamate/Glu & $306,7 \pm 69,26$ & $427,3 \pm 54,51$ & 0,136 \\
\hline Proline/Pro & $345,6 \pm 79,56$ & $565,6 \pm 82,83$ & 0,063 \\
\hline Serine/Ser & $330,4 \pm 73,97$ & $383,8 \pm 64,39$ & 0,470 \\
\hline Alanine/Ala & $74,5 \pm 16,41$ & $80,9 \pm 13,43$ & 0,683 \\
\hline Glutamine/Gln* & $22,2 \pm 2,57$ & $86,6 \pm 15,16$ & $<0,001$ \\
\hline Glycine/Gly & $4,2 \pm 0,99$ & $5,3 \pm 0,64$ & 0,136 \\
\hline Taurine/Tau & $1,3 \pm 0,31$ & $2,3 \pm 0,51$ & 0,088 \\
\hline 5-Hydroxylysine/Hyl & $15,3 \pm 2,75$ & $23,8 \pm 4,02$ & 0,105 \\
\hline
\end{tabular}




\section{Figure caption}

Figure 1. Diagnosis of leukemia-like neoplasia in L. balthica; a) normal haemolymph sample, b-c) haemolymph sample with high number of neoplastic cells (different magnifications), d) histological cross-section through normal L. balthica showing connective tissue of the digestive gland and male gonads and e) histological cross-section through highly neoplastic individual (corresponding to leukemia-like case shown in the Fig. 1 b-c) with neoplastic cells infiltrating the connective tissue around the digestive gland. Staining: a-c) methylene-blue, $d-e)$ basic hematoxylin and eosin.

Figure 2. ADA (a) and ALP (b) activities in haemolymph extracted from healthy ( $n=12$, black bars) and neoplastic ( $n=11$, red bars) individuals of $L$. balthica. Data presented as mean \pm S.E.M.

Figure 3. Mitochondrial oxygen consumption rate (OCR) of a) coupled mitochondria isolated from healthy ( $n=8$, black bars) and neoplastic ( $n=5$, red bars) clams in the presence of succinate (SUCC) and ADP as substrates, oligomycin (OLIGO) and antimycin A (AA) as inhibitors and CCCP as uncoupler; $b$ ) uncoupled mitochondria isolated from healthy ( $n=10$, black bars) and neoplastic clams $(n=7$, red bars) in the presence of pyruvate, malate (PYR+MAL) and succinate as substrates, rotenone (ROT) and antimycin A as inhibitors and Asc/TMPD as artificial electron acceptor; c) activity of SDH and COX in mitochondria form healthy ( $n=15$, black bars) and neoplastic ( $n=13$, red bars) clams. Data presented as mean \pm S.E.M. Asterisks indicate significant differences between healthy and neoplastic clams (Kruskal Wallis ANOVA, $p<0.05)$.

Figure 4. Antioxidative and physiological stress biomarkers responses in L. balthica tissues in healthy (black bars) and neoplastic (grey bars) clams: a) TAC (Total Antioxidant Capacity) level ( $n=5$ in both groups); b) AChE and GST activities, $n=6$ in both groups; c) protein carbonyl groups (CBO) level and lipid peroxidation products (MDA), $n=6$ in both groups. Data presented as mean \pm S.E.M. Asterisks indicate significant differences between healthy and neoplastic clams (Kruskal Wallis ANOVA, $p<0.05$ ).

Figure 5. Corticosteroids concentration in healthy (black bars) and neoplastic (white bars) L. balthica: a) CORT and D-CORT level ( $n=10$ in both groups); b) HCN and CN level ( $n=10$ in both groups). Data presented as mean \pm S.E.M. Asterisks indicate significant differences between healthy and neoplastic group (Kruskal Wallis ANOVA, $\mathrm{p}<0.05$ ). 

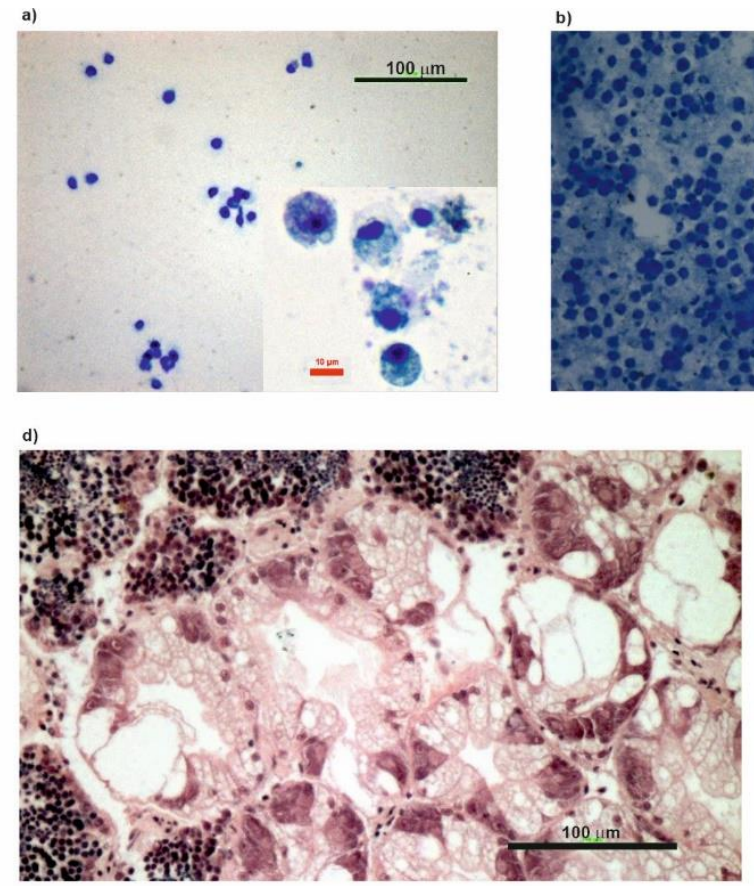
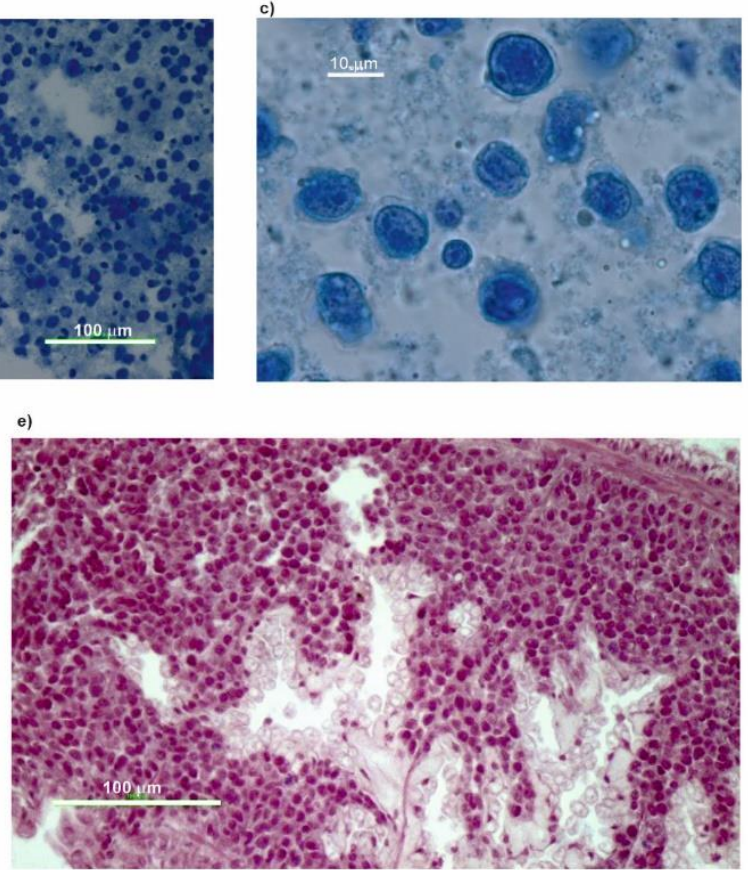

Fig. 1.
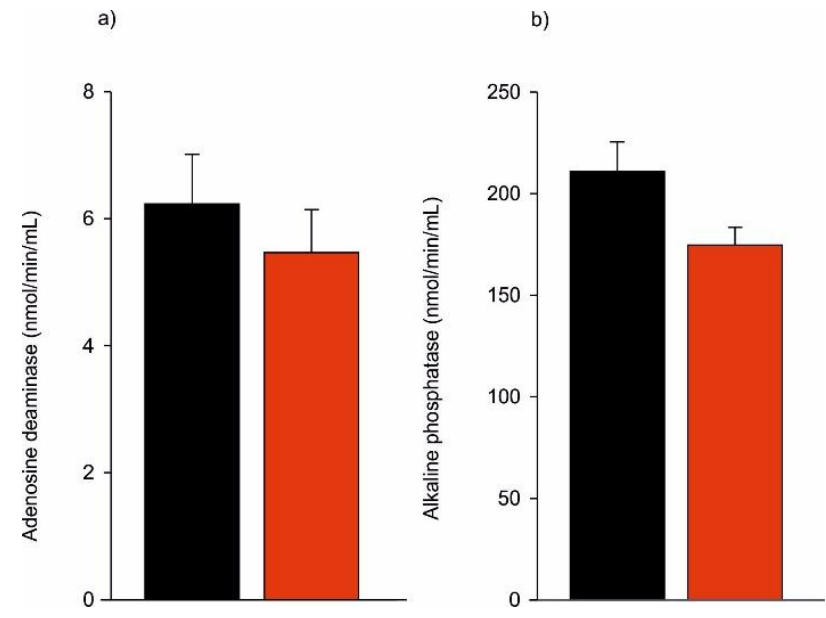

Fig. 2 


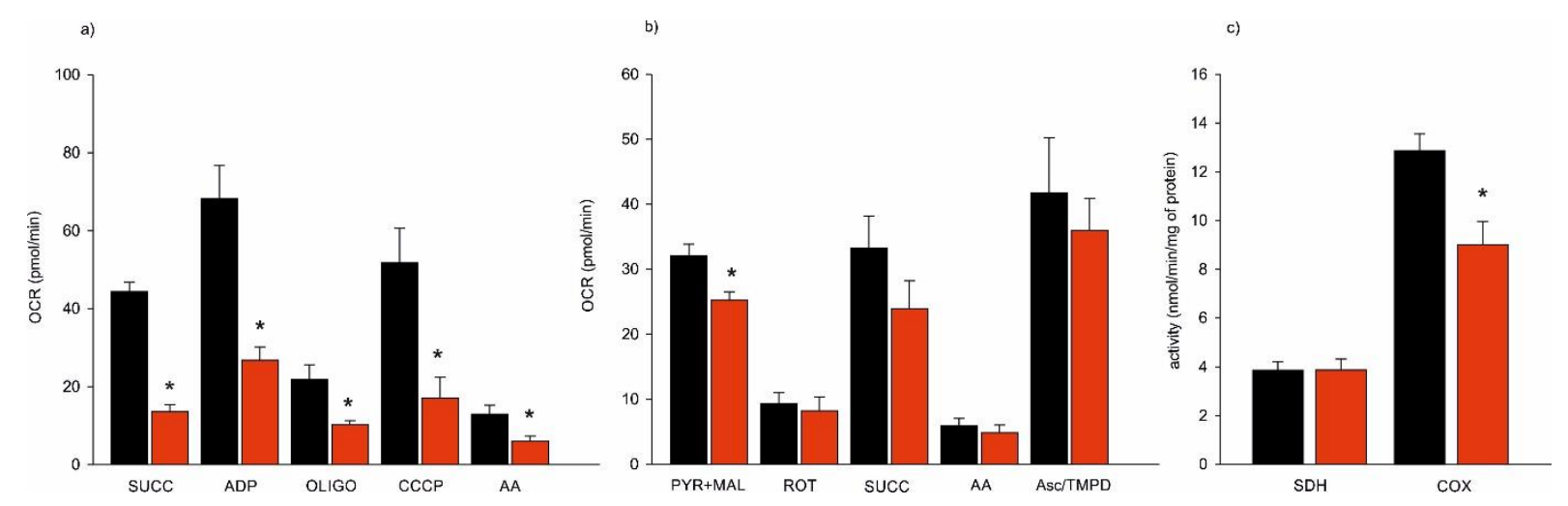

Fig. 3
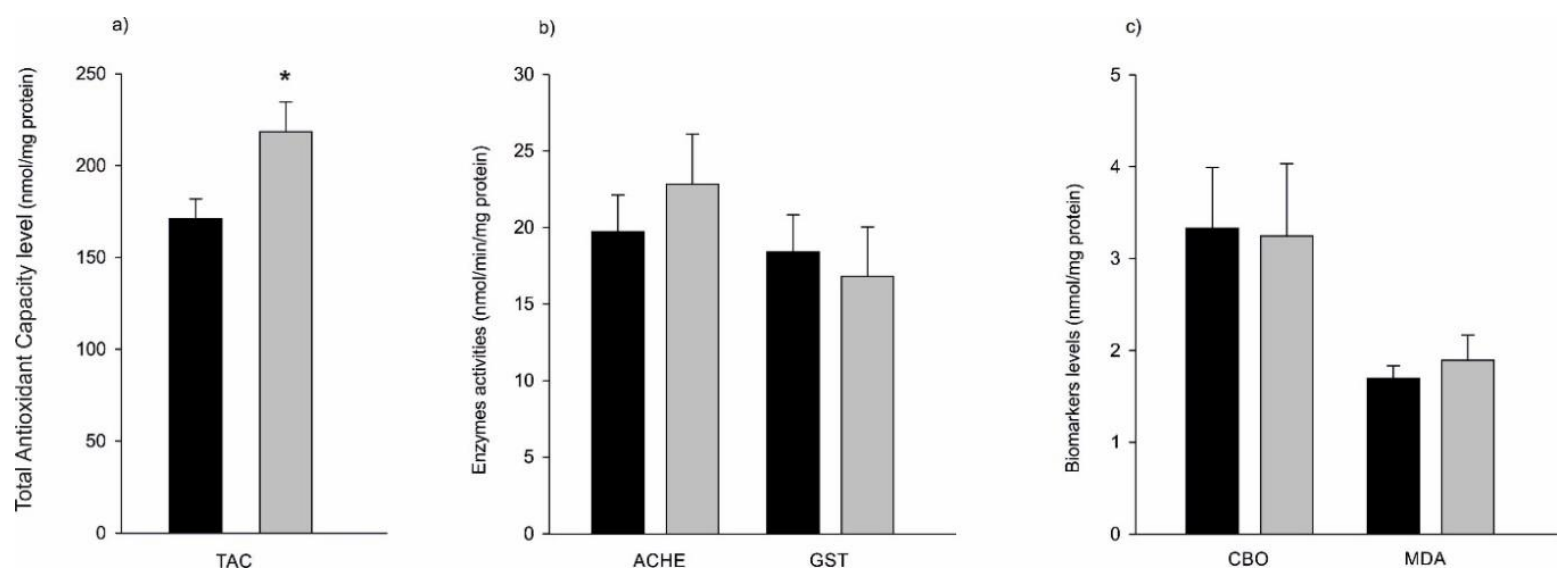

Fig. 4
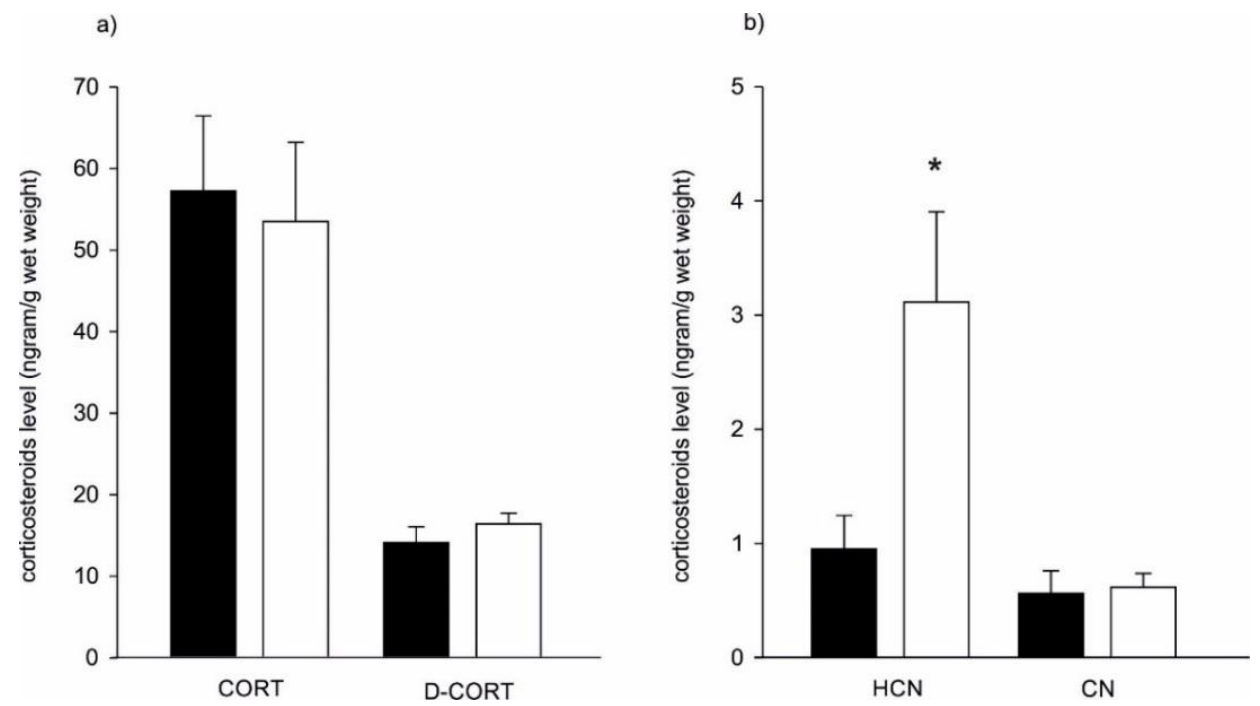

Fig. 5 


\section{Figures}

a)

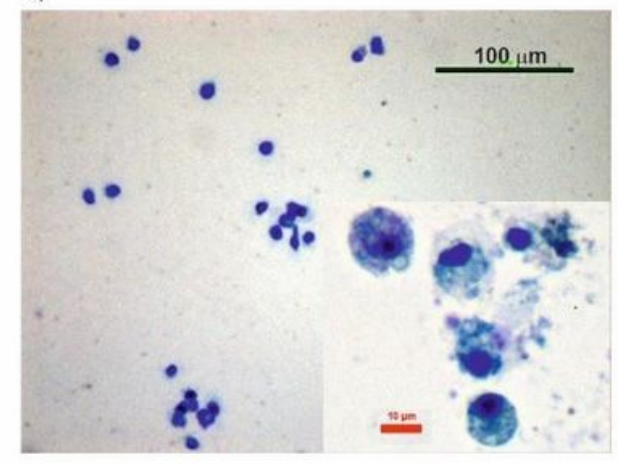

b)

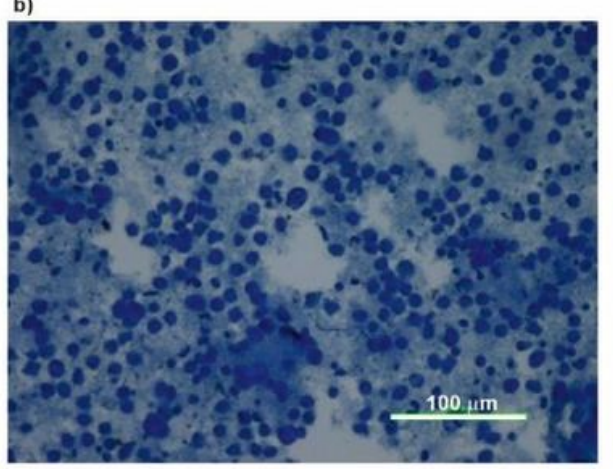

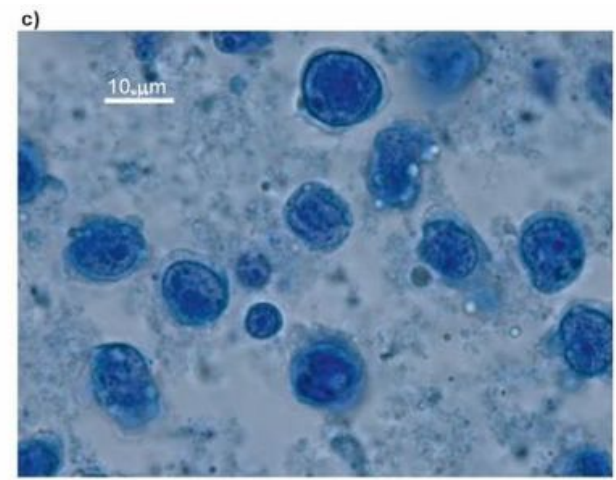

e)

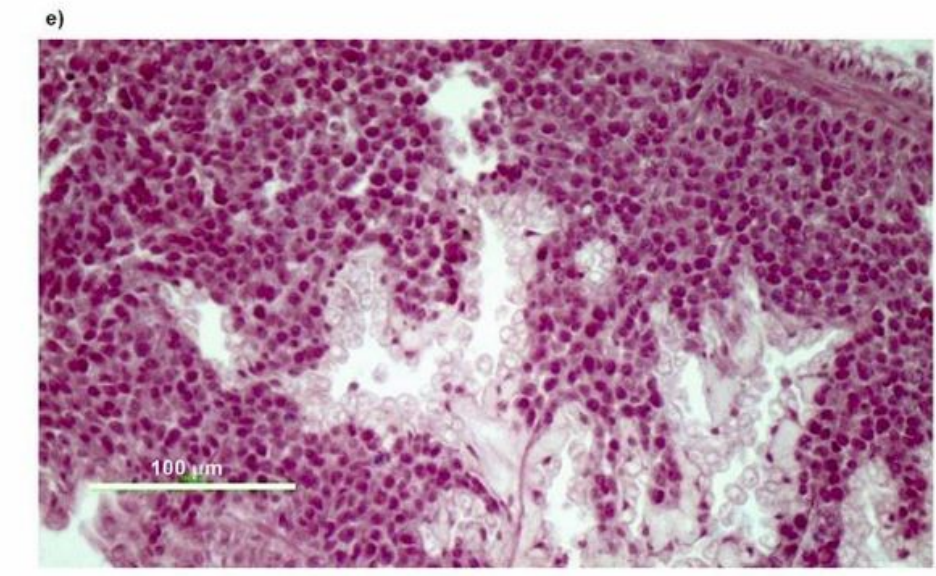

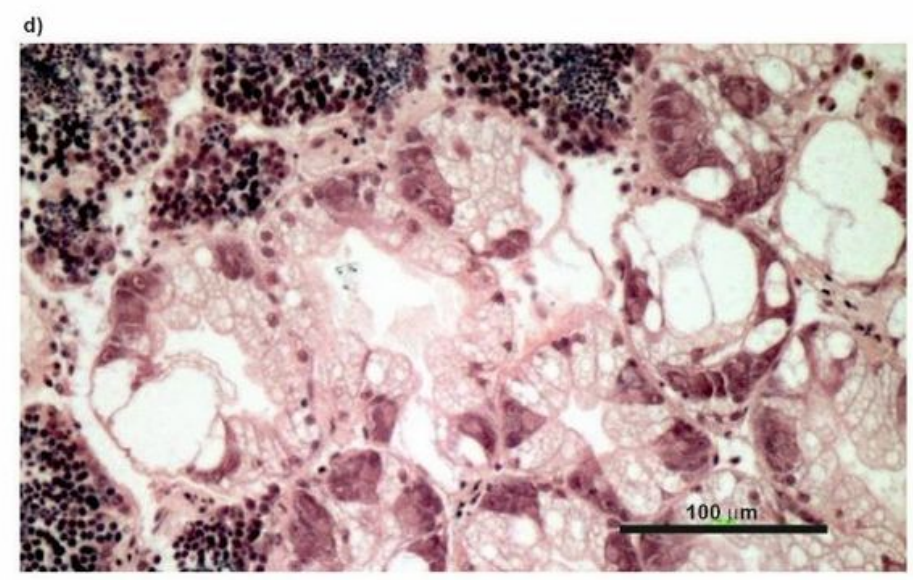

\section{Figure 1}

Diagnosis of leukemia-like neoplasia in L. balthica; a) normal haemolymph sample, b-c) haemolymph sample with high number of neoplastic cells (different magnifications), d) histological cross-section through normal L. balthica showing connective tissue of the digestive gland and male gonads and e) histological cross-section through highly neoplastic individual (corresponding to leukemia-like case shown in the Fig. 1b-c) with neoplastic cells infiltrating the connective tissue around the digestive gland. Staining: a-c) methylene-blue, d-e) basic hematoxylin and eosin. 
a)

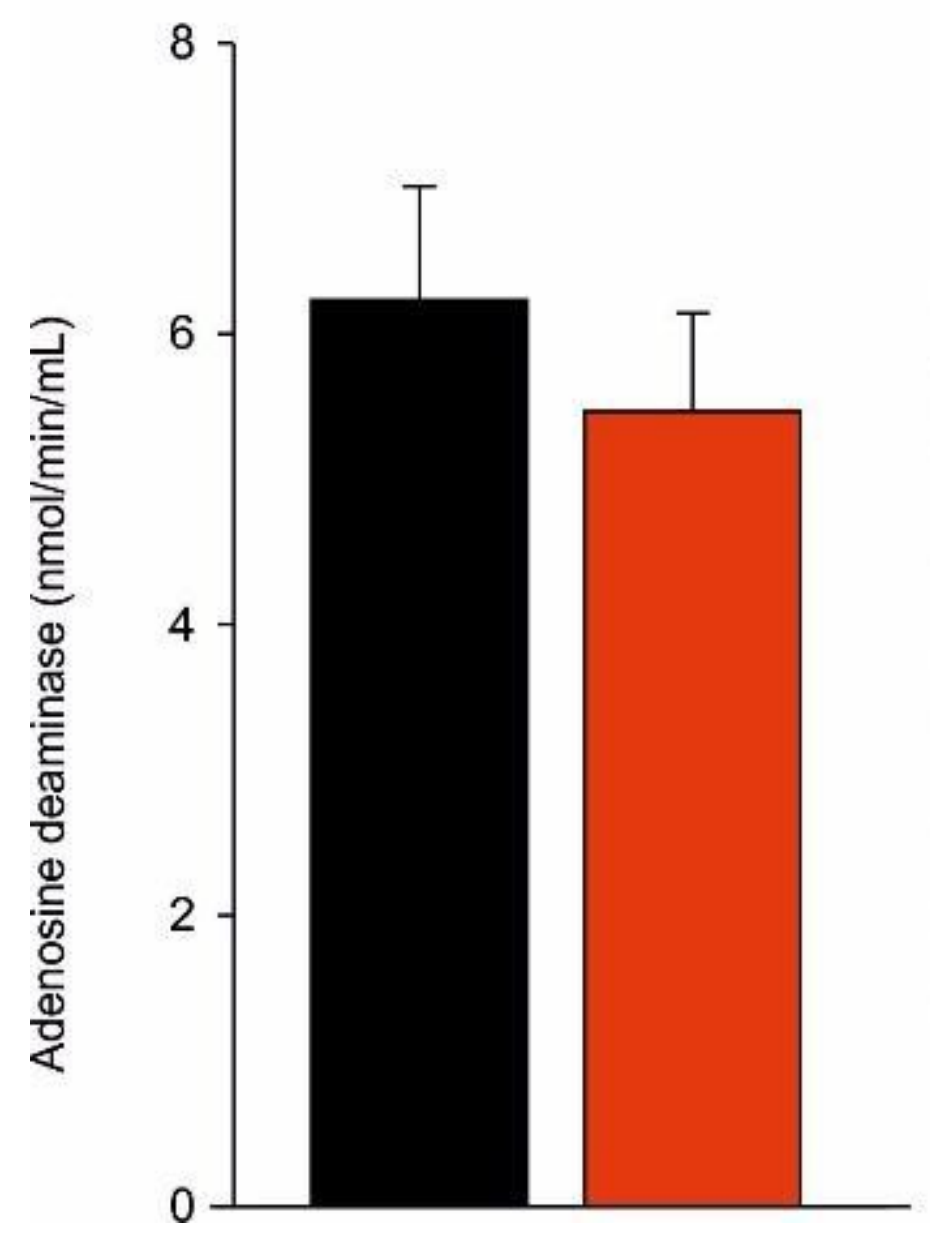

b)

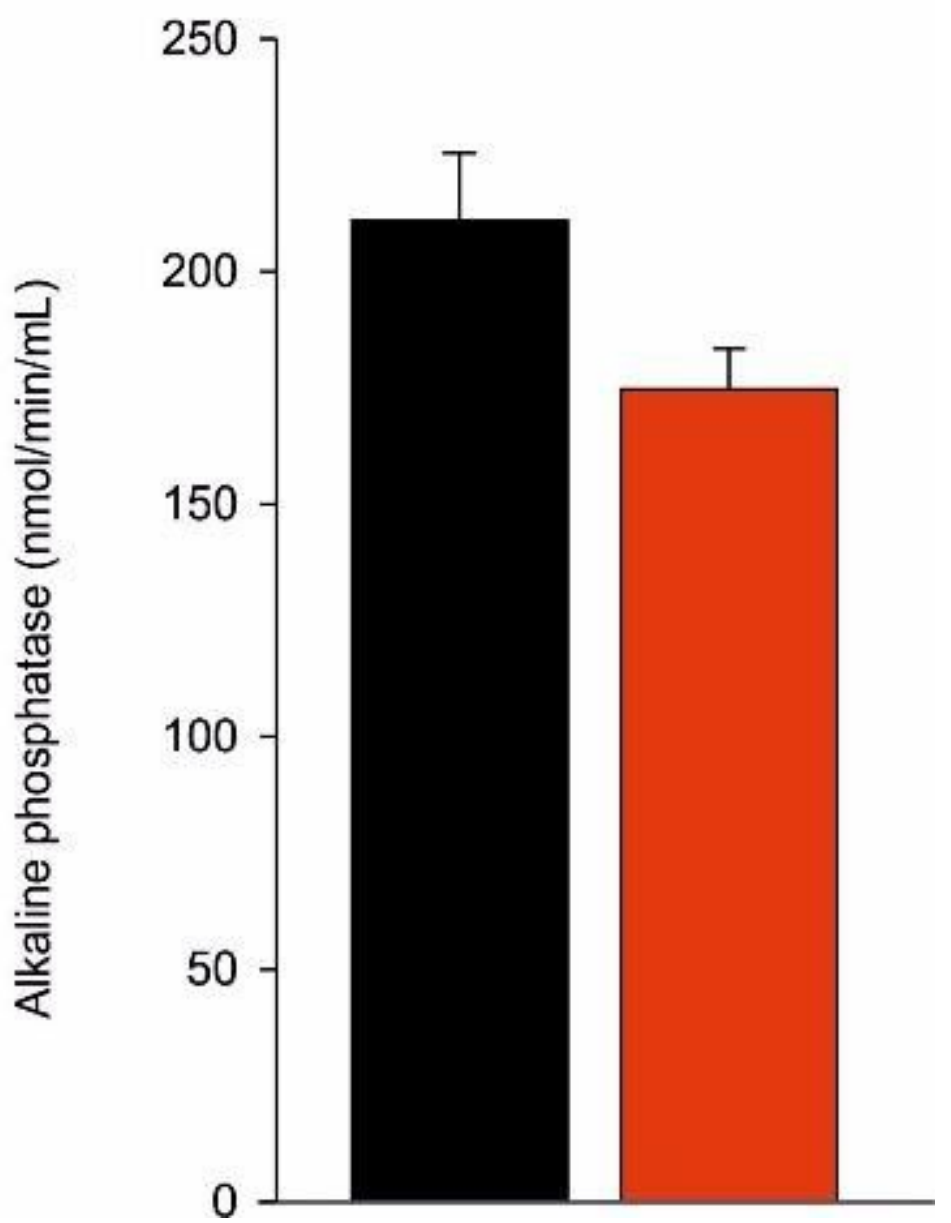

Figure 2

ADA (a) and ALP (b) activities in haemolymph extracted from healthy $(n=12$, black bars) and neoplastic ( $n=11$, red bars) individuals of L. balthica. Data presented as mean \pm S.E.M.
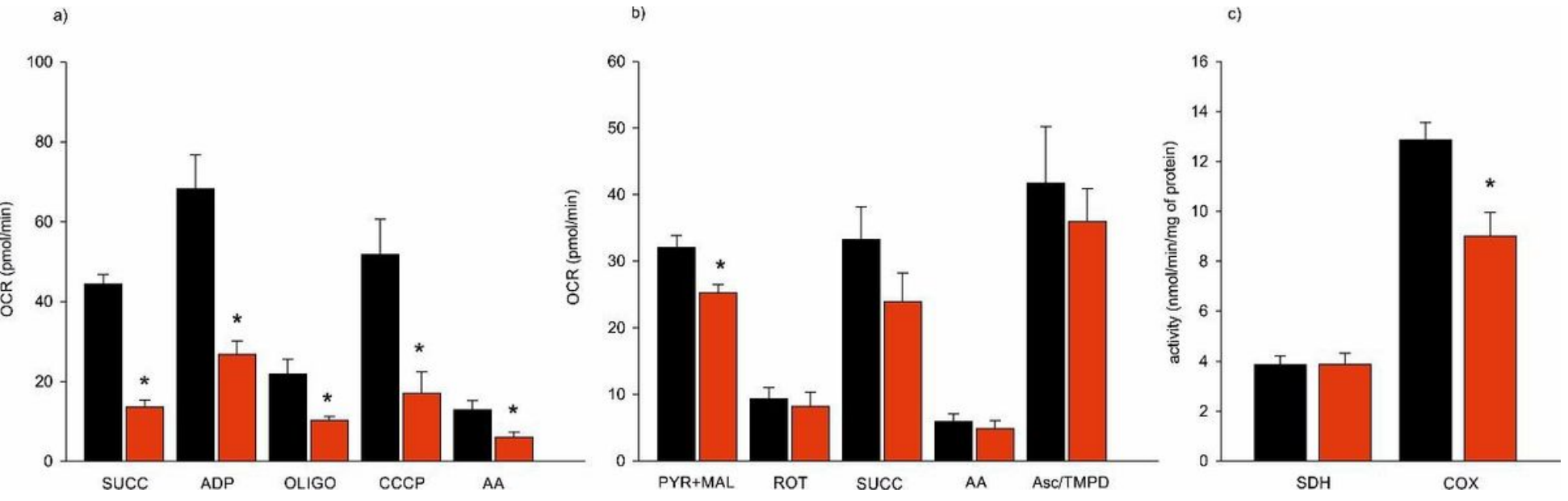

Figure 3 
Mitochondrial oxygen consumption rate (OCR) of a) coupled mitochondria isolated from healthy $(n=8$, black bars) and neoplastic ( $n=5$, red bars) clams in the presence of succinate (SUCC) and ADP as substrates, oligomycin (OLIGO) and antimycin A (AA) as inhibitors and CCCP as uncoupler; b) uncoupled mitochondria isolated from healthy ( $n=10$, black bars) and neoplastic clams ( $n=7$, red bars) in the presence of pyruvate, malate (PYR+MAL) and succinate as substrates, rotenone (ROT) and antimycin $A$ as inhibitors and Asc/TMPD as artificial electron acceptor; c) activity of SDH and COX in mitochondria form healthy ( $n=15$, black bars) and neoplastic $(n=13$, red bars) clams. Data presented as mean \pm S.E.M. Asterisks indicate significant differences between healthy and neoplastic clams (Kruskal Wallis ANOVA, $p$ $<0.05)$.

a)

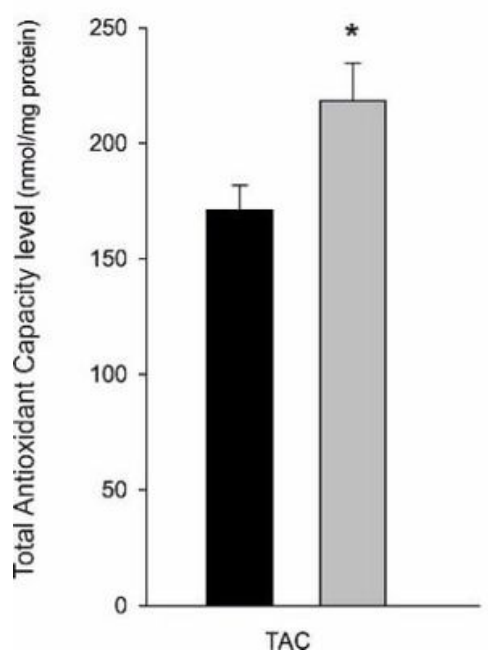

b)

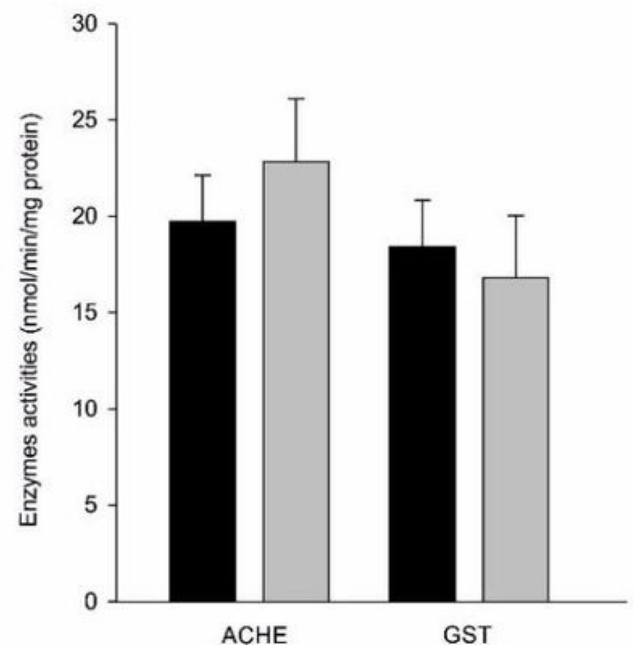

c)

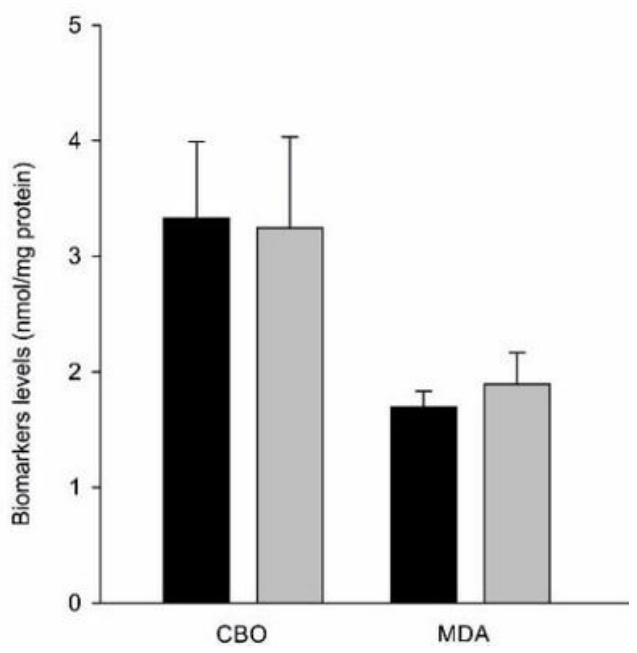

\section{Figure 4}

Antioxidative and physiological stress biomarkers responses in L. balthica tissues in healthy (black bars) and neoplastic (grey bars) clams: a) TAC (Total Antioxidant Capacity) level ( $n=5$ in both groups); b) AChE and GST activities, $n=6$ in both groups; $c$ ) protein carbonyl groups (CBO) level and lipid peroxidation products (MDA), $n=6$ in both groups. Data presented as mean \pm S.E.M. Asterisks indicate significant differences between healthy and neoplastic clams (Kruskal Wallis ANOVA, $p<0.05$ ). 
a)

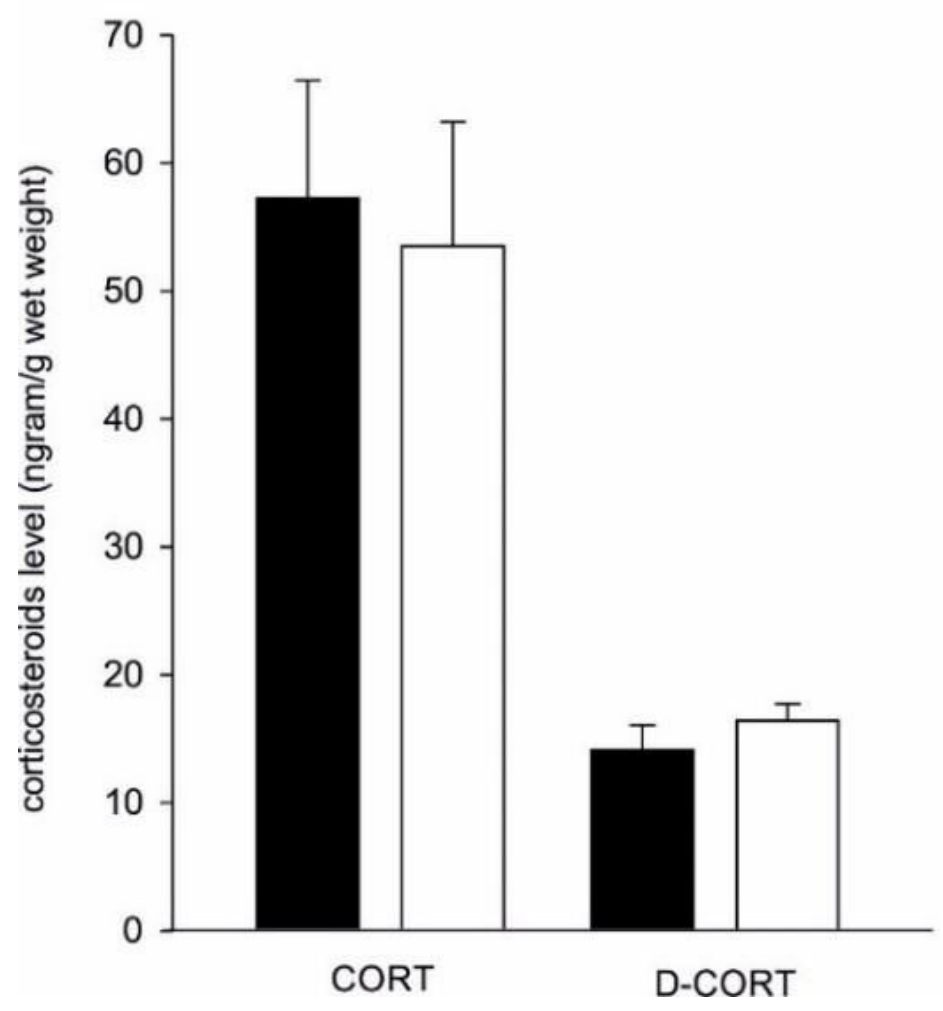

b)

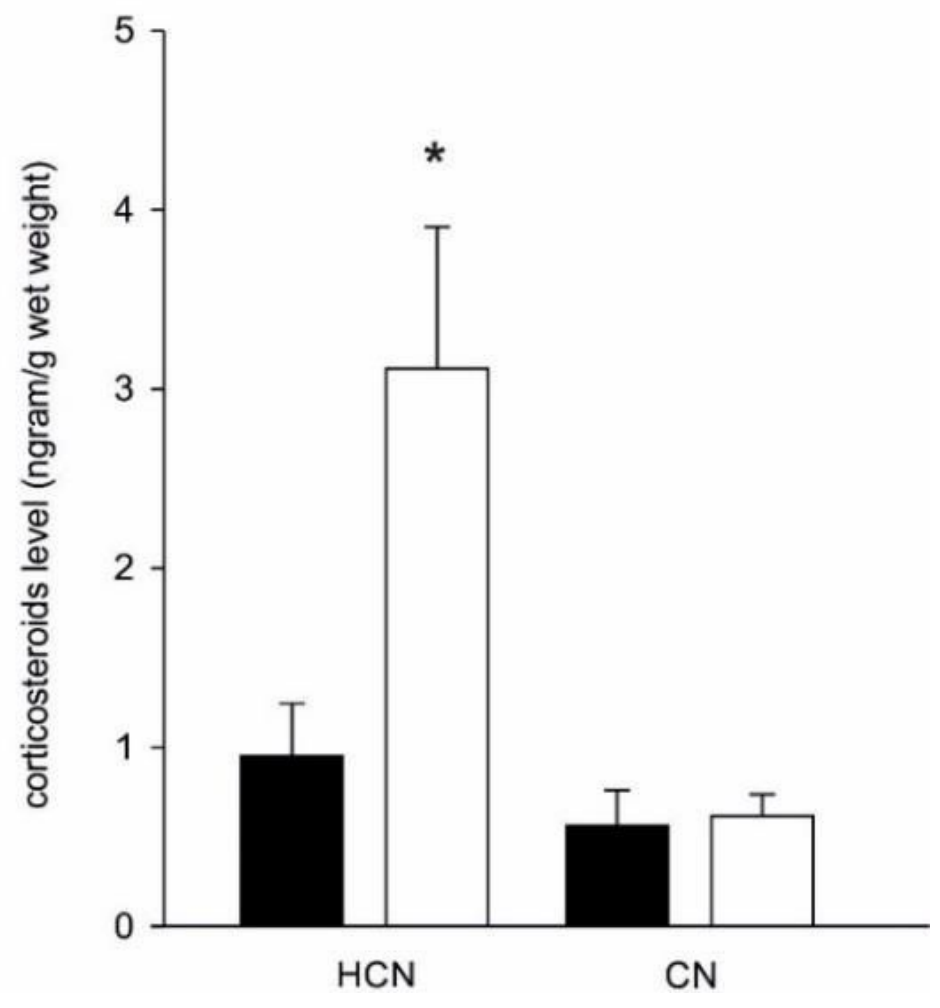

Figure 5

Corticosteroids concentration in healthy (black bars) and neoplastic (white bars) L. balthica: a) CORT and D-CORT level ( $n=10$ in both groups); b) HCN and CN level ( $n=10$ in both groups). Data presented as mean \pm S.E.M. Asterisks indicate significant differences between healthy and neoplastic group (Kruskal Wallis ANOVA, $p<0.05)$. 